2019-06-01

\title{
Role of recent climate change on carbon sequestration in peatland systems.
}

\author{
Lunt, Paul
}

http://hdl.handle.net/10026.1/13514

10.1016/j.scitotenv.2019.02.239

Science of the Total Environment

Elsevier

All content in PEARL is protected by copyright law. Author manuscripts are made available in accordance with publisher policies. Please cite only the published version using the details provided on the item record or document. In the absence of an open licence (e.g. Creative Commons), permissions for further reuse of content should be sought from the publisher or author. 


\section{Role of recent climate change on carbon sequestration in peatland systems}

$2 \quad *$ Dr Paul H. Lunt, Prof. Ralph M. Fyfe and Dr Alan D. Tappin

$3 *$ Corresponding author. School of Geography, Earth and Environmental Science, Portland

4 Square, Drake Circus Plymouth University, Plymouth, Devon PL4 8AA.

5 paul.lunt@plymouth.ac.uk. 01782584580

\section{Highlights}

- Mean rates of carbon accumulation since 1850 were $11.26 \mathrm{t} \pm 0.68 \mathrm{t} \mathrm{CO}_{2} \mathrm{e} \mathrm{ha}^{-1} \mathrm{yr}^{-1}$ for valley mire and $11.77 \mathrm{t} \pm 0.88 \mathrm{t} \mathrm{CO}_{2} \mathrm{e} \mathrm{ha}^{-1} \mathrm{yr}^{-1}$ for blanket bog

- Contemporary rate of $\mathrm{CO}_{2}$ sequestration was $9.13 \mathrm{t} \pm 0.98 \mathrm{t} \mathrm{CO}_{2} \mathrm{e} \mathrm{ha}^{-1} \mathrm{yr}^{-1}$

- Past and contemporary peatland carbon sinks were found to be at the upper limits of those reported in the literature

- Recent changes in climate appear to have had minimal impact on the strength of peatland carbon sinks in South West England

\section{Abstract}

This paper provides information on the impact of recent climate change on carbon sequestration in peatland systems in South West England. This is important because peatlands have the potential to sequester and hold large quantities of anthropogenically released $\mathrm{CO}_{2}$. This paper investigates whether there has been a reduction in the strength of carbon sinks in a valley mire and blanket bog; which occur on the limits of the biogeographical envelop for peatlands in Britain. Past rates of carbon accumulation were determined from peat depth and the sequential analysis of peat age, bulk density and carbon content from cores taken from valley mire and blanket bog. At the valley mire site contemporary net ecosystem carbon balance (NECB) was calculated by measuring inputs to 
the peat body, via net primary productivity (NPP), of Sphagna. Losses of C from the peat body were calculated by measuring $\mathrm{CH}_{4}$, and aquatic carbon; calculated from catchment export of particulate and dissolved organic carbon. The study found similar mean rates of carbon accumulation since 1850 of $11.26 \mathrm{t} \pm 0.68 \mathrm{t} \mathrm{CO}_{2} \mathrm{e} \mathrm{ha}^{-1} \mathrm{yr}^{-1}\left(307 \mathrm{~g} \mathrm{C} \mathrm{m}^{-2} \mathrm{yr}^{-1}\right)$ in valley mire and $11.77 \mathrm{t} \pm 0.88 \mathrm{t} \mathrm{CO}_{2} \mathrm{e} \mathrm{ha}^{-1} \mathrm{yr}^{-1}\left(321 \mathrm{~g} \mathrm{C} \mathrm{m}^{-2} \mathrm{yr}^{-1}\right)$ in blanket bog. The mean present-day $\mathrm{CO}_{2}$ sequestration rate for Sphagna on valley mire was calculated to be $9.13 \mathrm{t} \pm 0.98 \mathrm{t} \mathrm{CO}_{2} \mathrm{e} \mathrm{ha}^{-1} \mathrm{yr}^{-1}\left(249 \mathrm{~g} \mathrm{C} \mathrm{m}^{-2} \mathrm{yr}^{-1}\right)$. Both past and contemporary rates of $\mathrm{CO}_{2}$ sequestration were found to be at the upper limits of those reported in the literature for temperate peatlands. NPP was found to vary according to microform with higher rates of carbon sequestration found in lawn and hummock microforms compared with pools. Our work suggests that recent changes in the climate appear to have had limited impact on the strength of peatland carbon sinks in South West England.

\section{Key Words}

$\mathrm{CO}_{2}$ sequestration; peatlands; Sphagnum; net ecosystem carbon balance; climate change; peat accumulation

The authors use the term net ecosystem carbon balance (NECB), as defined in Chapin et al., (2006) to describe carbon uptake in peatlands. All values for carbon are presented as $\mathrm{CO}_{2}$ equivalents ( $\mathrm{t} \mathrm{CO}_{2} \mathrm{e} \mathrm{ha}^{-1} \mathrm{yr}^{-1}$ ), where carbon $(\mathrm{C})$ is converted to $\mathrm{CO}_{2}$ based on molecular mass difference by multiplying the amount of $\mathrm{C}$ by 3.667. Where values are cited from the

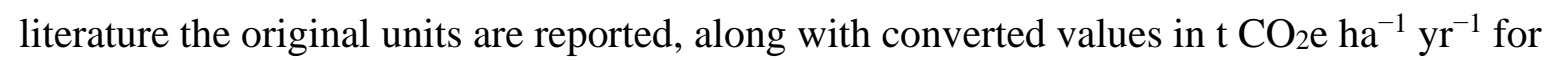
comparison. 'Carbon accumulation' refers to carbon accumulated as peat. The term 'Carbon exchange' has been used where $\mathrm{CO}_{2}$ fluxes have been measured. 'Carbon balance' is the difference between $\mathrm{CO}_{2}$ uptake by the peatland ecosystem (photosynthesis) and $\mathrm{CO}_{2}$ loss to 
47 the atmosphere by respiration. 'Carbon sequestration' refers to is the removal and storage of carbon from the atmosphere in peat.

49

50

\subsection{Introduction}

Peatlands have the highest carbon storage capacity per unit area of all terrestrial ecosystems (Brooks \& Stoneman, 1997; Worrall et al. 2009; Yu et al. 2011b). Cox et al. (2000) estimated globally that 60 gigatonnes of carbon $(\mathrm{Gt} C)$ are removed each year from the atmosphere by NPP of photosynthetic plants. Known peatlands are estimated to cover $3-4 \%$ of the world's land area (Gorham, 1991; Parish et al. 2008; Xu et al. 2018) and contain $\sim 612 \mathrm{Gt} \mathrm{C}$ (Yu et al. 2011b). Variation in the size of the peatland carbon sink could have a significant cumulative effect on global atmospheric $\mathrm{CO}_{2}$ concentrations (Chambers \& Charman, 2004; Charman et al. 2013). Estimates of global carbon accumulation by peatlands

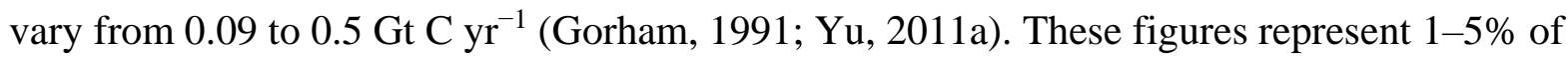
global annual anthropogenic greenhouse gas (GHG) emissions (Friedlingstein et al. 2014). Globally, appropriate protection and management of peatlands is one of the most costeffective measures in reaching the ultimate goal of zero net carbon emissions from the landuse management sector (Ostle et al. 2009).

Peatlands cover $24,600 \mathrm{~km}^{2}$ or $\sim 15 \%$ of the land area and store $2.3-3.12 \mathrm{Gt} \mathrm{C}$ in the UK (Billett et al. 2010; Lindsay \& Clough 2017). Peatlands have the potential to sequester and hold large quantities of anthropogenically-released atmospheric $\mathrm{CO}_{2}$, making a significant contribution to international GHG budgets (Waddington et al. 2010; Bain et al. 2011; Yu, 2011a). Research on rates of carbon sequestration on peatlands has focused on two approaches: contemporary gaseous exchange of $\mathrm{CO}_{2}$ using eddy covariance measurements (Billett et al. 2010; Helfter et al. 2015; Levy \& Gray 2015; Wilson et al. 2016) and Holocene rates of carbon accumulation established from peat cores (Pendea \& Chmura 2012; Charman 
et al. 2013). Chamber studies have also been widely used in the UK and elsewhere to investigate net carbon balance (Rowson et al. 2010; Dixon et al. 2014; Gatis et al. 2015;

Green et al. 2018).

Net ecosystem carbon balance (NECB: Chapin et al. 2006) models can be used to assess contemporary rates of carbon gain and loss from peatlands. In recent years there has been a significant amount of work to understand the factors effecting site-level NECB values. Dinsmore et al. (2010) found contemporary site-level NECB of $3.52 \mathrm{t} \mathrm{CO}_{2} \mathrm{e} \mathrm{ha}^{-1} \mathrm{yr}^{-1}(352 \mathrm{~g}$ $\mathrm{CO}_{2} \mathrm{~m}^{-2} \mathrm{yr}^{-1}$ ) in a UK ombrotrophic peatland whilst Billett et al. (2010) report contemporary site-level NECB in two ombrotrophic peatlands of 2.05-2.64 $\mathrm{t} \mathrm{CO}_{2} \mathrm{e} \mathrm{ha}^{-1} \mathrm{yr}^{-1}\left(56-72 \mathrm{~g} \mathrm{C} \mathrm{m}^{-2}\right.$ $\left.\mathrm{yr}^{-1}\right)$. Values reported for NECB in boreal and northern continental peatlands of the Northern Hemisphere are typically at the lower end of the range reported for undisturbed peatlands at $0.79 \mathrm{t} \mathrm{CO}_{2} \mathrm{e} \mathrm{ha}^{-1} \mathrm{yr}^{-1}\left(21.5 \pm 39.0 \mathrm{~g} \mathrm{C} \mathrm{m}^{-2} \mathrm{yr}^{-1}\right)$ (Roulet et al. 2007; Payne et al. 2016). These findings suggest that there is a great deal of variability in NECB due to latitude and geographical location as well as mire community type (Billett et al. 2010; Dinsmore et al. 2010; House et al., 2010; Koehler et al. 2011).

Gorham (1991) estimated mean rates of accumulation of $0.84 \mathrm{t} \mathrm{CO}_{2} \mathrm{e} \mathrm{ha}^{-1} \mathrm{yr}^{-1}$ for boreal and subarctic peatlands during the Holocene based on peat cores and these values are broadly similar to NECB for boreal and northern continental peatlands. In Canada, Roulet et al. (2007) compared contemporary carbon exchange with apparent C accumulation over 3000 years and found similar levels of carbon accumulation in contemporary site-level net ecosystem $\mathrm{C}$ exchange $\left(0.78 \mathrm{t} \pm 1.43 \mathrm{t} \mathrm{CO}_{2} \mathrm{e} \mathrm{ha}^{-1} \mathrm{yr}^{-1}\right)$ and dated peat cores $(0.8 \mathrm{t} \pm 0.1-$ $\left.0.51 \pm 1.37 \mathrm{t} \mathrm{CO}_{2} \mathrm{e} \mathrm{ha}^{-1} \mathrm{yr}^{-1}\right)$. In spite of this apparent agreement there is a great deal of variability in rates of peat accumulation from peat cores in response to climate and geographical location (Belyea \& Clymo, 2001). For example, Belyea and Malmer (2004) report values between $0.51-2.64 \mathrm{t} \mathrm{CO}_{2} \mathrm{e} \mathrm{ha}^{-1} \mathrm{yr}^{-1}\left(14-72 \mathrm{~g} \mathrm{C} \mathrm{m}^{-2} \mathrm{yr}^{-1}\right)$, with higher rates 
associated with climatic optima during periods of higher temperatures and rainfall. Levy and

Gray (2015) found that the contemporary carbon sink in blanket bog in northern Scotland was larger than estimates from local peat cores, based on peat accumulation over the last several thousand years. Whilst mean rates of carbon accumulation across Holocene time scales appears to match contemporary carbon exchange we can observe significant variation through the course of the Holocene [illustrated by Belyea \& Malmer, 2004], with variation in carbon sequestration controlled by changes in net primary productivity forced by temperature and cloudiness variability (Charman et al. 2013).

Net primary productivity (NPP) is by far the largest constituent of a NECB model in an active peatland (Moore et al. 2002; Nilsson et al. 2008; Billett et al. 2010). Koehler et al. (2011) measured components of site-level NECB over a six year period in an ombrotrophic mire in southern Ireland, and found mean annual carbon uptake was $29.7 \pm 30.6( \pm 1 \mathrm{SD}) \mathrm{g} \mathrm{C}$ $\mathrm{m}^{-2} \mathrm{yr}^{-1}\left(1.09 \mathrm{t} \pm 1.12 \mathrm{t}( \pm 1 \mathrm{SD}) \mathrm{CO} 2 \mathrm{e} \mathrm{ha}^{-1} \mathrm{yr}^{-1}\right)$. The main components of their NECB were as follows: carbon uptake in $\mathrm{CO}_{2}$ from the atmosphere was $47.8 \pm 30.0 \mathrm{~g} \mathrm{C} \mathrm{m}^{-2} \mathrm{yr}^{-1}$ $\left(1.75 \mathrm{t} \pm 0.01 \mathrm{t} \mathrm{CO}^{\mathrm{e}} \mathrm{ha}^{-1} \mathrm{yr}^{-1}\right)$; carbon loss as $\mathrm{CH}_{4}$ was $4.1 \pm 0.5 \mathrm{~g} \mathrm{C} \mathrm{m}^{-2} \mathrm{yr}^{-1}$ $\left(0.15 \mathrm{t} \pm 0.018 \mathrm{t} \mathrm{CO} 2 \mathrm{e} \mathrm{ha}^{-1} \mathrm{yr}^{-1}\right)$; and the carbon exported as stream-dissolved organic carbon (DOC) was a loss of $14.0 \pm 1.6 \mathrm{~g} \mathrm{C} \mathrm{m}^{-2} \mathrm{yr}^{-1}\left(0.51 \mathrm{t} \pm 0.059 \mathrm{t} \mathrm{CO}^{\mathrm{e}} \mathrm{ha}^{-1} \mathrm{yr}^{-1}\right)$. For two out of the six years, the site was a source of carbon with the sum of $\mathrm{CH}_{4}$ and DOC flux exceeding the carbon sequestered as $\mathrm{CO}_{2}$.

In northern peatlands, Sphagnum mosses dominate the surface cover of pristine, ombrotrophic bogs and often account for a significant proportion of past accumulated peat. Sphagnum productivity is controlled by mean annual temperature, precipitation and photosynthetically active radiation (PAR) (Gunnarsson, 2005; Loisel et al. 2012; Nijp et al. 2015). As previously outlined, Charman et al. (2013) found that total carbon accumulated over the last 1000 years is linearly related to growing season length and PAR, demonstrating 
changes in peat body carbon sequestration with climatic change. Climate change alters rates

122

123

124

125

126

127

128

Dartmoor represents the largest extent of blanket mire in southern England with an estimated

$144158 \mathrm{~km}^{2}$ of peat having a depth greater than $0.4 \mathrm{~m}$ (Gatis et al. 2019). The upland is 
composed of an eroded granite plateau, of elevation range $300-623 \mathrm{~m}$, with an annual mean

$14717.7^{\circ} \mathrm{C}$ (July) with a mean rainfall of $1974 \mathrm{~mm} \mathrm{yr}^{-1}$ and ca. 180.9 days of rainfall (> $\left.1 \mathrm{~mm}\right)$,

148 (Met Office 2017: 1971-2000 averages). All months have an average of over $100 \mathrm{~mm}$

149 rainfall, with the four wetter months over $200 \mathrm{~mm}$.

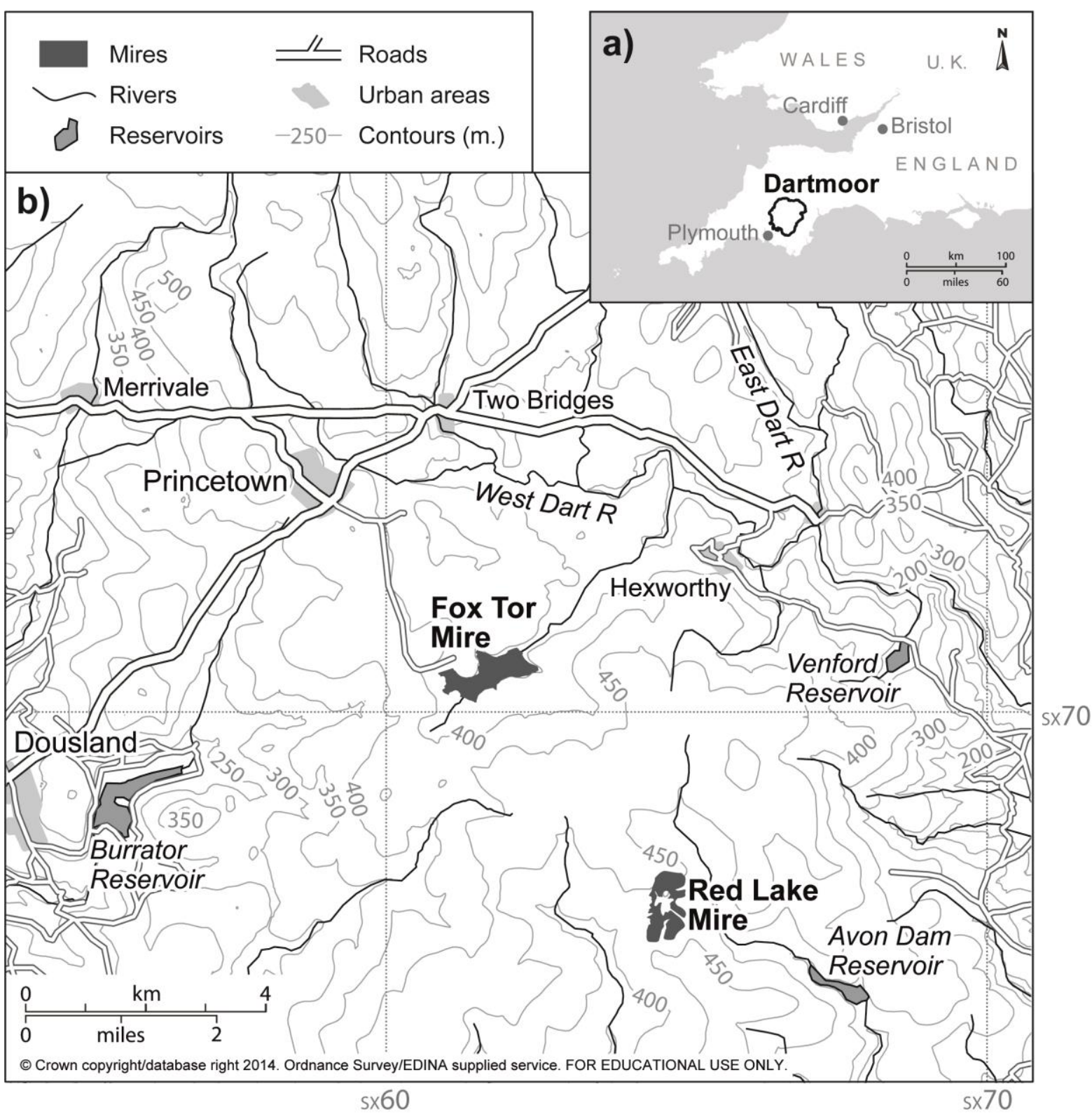


152 Fig. 1 (a) Regional map showing the location of Dartmoor within South West England; (b)

153 Locations of Fox Tor Mire and Red Lake Mire study sites

154 Footnote Fox Tor Mire provided the inspiration for Arthur Conan Doyle's fictional Grimpen

155 Mire, in the Sherlock Holmes story, The Hound of the Baskervilles.

156 Data were collected from two contrasting intact mire sites on Dartmoor, Fox Tor Mire and

157 Red Lake (Fig. 1). Fox Tor Mire is a valley mire, with a 58.3 ha peat body, located $4 \mathrm{~km}$

158 south-east of Princetown $\left(50.517^{\circ} \mathrm{N}, 03.956^{\circ} \mathrm{W}\right)$ at an elevation of $351 \mathrm{~m}$. Almost all of the

159 previous peat deposits at Fox Tor Mire were removed during commercial peat mining

160 operations which ceased in the 1850s (Wright, 1884). A layer of mine washings occurred at

161 the base of the peat column, which was dated to a period of extensive mining at White Works

162 on the periphery of the mire, in 1876 (Wright, 1884). All subsequent peat developed in the

163 period following 1876. Plant communities are intermediate between soligenous and

164 ombrogenous mire. Sample areas were permanently saturated and Sphagnum-dominated,

165 consisting primarily of National Vegetation Classification (NVC) communities M15b and

166 M6, Scirpus cespitosus-Erica tetralix wet heath and Carex echinata-Sphagnum

167 fallax/denticulatum mire (Rodwell, 1991). The three dated peat cores were taken from

168 separate areas with surface vegetation typical of nutrient poor fen, constant species included

169 Eriophorum angustifolium, Sphagnum papillosum, Sphagnum fallax, Sphagnum

170 denticulatum, Molinia caerulea and Menyanthes trifoliata.

171 Red Lake Mire is a precipitation-only ombrotrophic blanket bog, situated $8.5 \mathrm{~km}$ south-east of

172 Princetown, $\left(50.488^{\circ} \mathrm{N}, 03.910^{\circ} \mathrm{W}\right)$ at an elevation of $470 \mathrm{~m}$. The main vegetation community

173 consists of Scirpus cespitosus-Eriophorum vaginatum blanket mire (NVC code M17) with a

174 Sphagnum base layer overlying a hummock and hollow microtopography. Peat cores were

175 taken from an area to the north of Red Lake, with an intact primary bog surface. Ground and 
176 LIDAR observations showed several drainage ditches local to the area which were infilled with

177 peat-forming vegetation. Sphagna were present in all quadrats, with S. papillosum (87\%) and

178 S. cuspidatum (61\%) having the highest abundance. Other constant species included 179 Eriophorum angustifolium (85\%), E. vaginatum (71\%), Narthecium ossifragum (71\%) and 180 Trichophorum cespitosum (59\%).

\section{$181 \quad 2.0$ Methods}

\section{$182 \quad 2.1$ Measurement of past rates of carbon accumulation}

183 Apparent past rates of carbon accumulation were determined for Red Lake Mire (blanket bog) and Fox Tor Mire (valley mire) using a multi-technique approach on replicate peat cores, extracted using a $5 \mathrm{~cm}$ diameter semi-circular Russian peat corer.

Three cores were extracted from three separate areas of Fox Tor Mire. Cores were $\sim 150 \mathrm{~cm}$ in length and consisted of the entire column of peat, down to the mineral layer. Cores were dated using sequential analysis of concentrations of Spheroidal Carbonaceous Particles (SCPs), combined with the presence of a definitive alluvial deposit dated to 1876.

In addition to the three cores taken for SCP analysis, a further 20 cores were extracted from across Fox Tor Mire. Mean rates of peat accumulation on these cores were determined by the presence of an alluvial mineral layer, widely deposited at the base of peat cores by washings, from the White Works mine on the periphery of the mire. This layer provided a definitive

194 marker dated to 1876.

195 At Red Lake Mire, four $100 \mathrm{~cm}$ long cores were extracted from three separate unmodified 196 active mire areas. Three cores were dated using sequential analysis of SCPs, combined with 197 X-Ray Florescence (XRF) readings and a fourth core was dated using known peaks in the 198 radionuclides ${ }^{210} \mathrm{~Pb}$ and ${ }^{137} \mathrm{Cs}$. 


\subsubsection{Dating ranges using Spheroidal Carbonaceous Particles (SCPs)}

200

201

202

203

204

205

206

207

208

209

210

211

212

213

214

215 216 (Pendea \& Chmura, 2012).

217 Equation: Peat Accumulation Rate (AR) in $\mathrm{cm} \mathrm{yr}^{-1}$

218

219

220 the core.

$$
A R=D \div T
$$

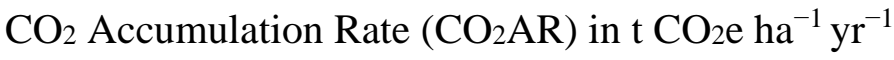

Analysis of SCPs was the principal method used to obtain dates and dating ranges (Swindles, 2010). SCP analysis was undertaken on cores following the method outlined by Rose et al. (1995). Peat cores were cut into $2 \mathrm{~cm}$ segments at $5 \mathrm{~cm}$ intervals throughout their depths. SCP densities and linear accumulation rates were calculated for individual segments down

Laboratory protocol for measurement of bulk density and calculation of ash-free carbon content $\left(\mathrm{g} \mathrm{C} \mathrm{cm}^{-3}\right)$ followed the method outlined by Chambers et al. (2011). Bulk density ( $\mathrm{g}$ $\mathrm{cm}^{-3}$ ) was determined by measuring the dry weight $(\mathrm{g})$ divided by fresh sample volume $\left(\mathrm{cm}^{3}\right)$. To increase accuracy, sample volumes were measured by water displacement following the method set out by Buffam et al. (2010). Samples were oven dried $\left(100^{\circ} \mathrm{C}\right)$ to constant weight and ashed in a furnace at $550^{\circ} \mathrm{C}$ for 4 hours to determine ash-free dry weight and organic matter content (Chambers et al. 2011). Ash-free carbon content $\left(\mathrm{g} \mathrm{C} \mathrm{cm}^{-3}\right)$ was calculated by multiplying the bulk density by $51 \%$ (mean $\%$ fraction of ash-free carbon for Sphagnum peat). Carbon masses were up-scaled to $\mathrm{t} \mathrm{ha}^{-1} \mathrm{~cm}^{-1}$, and converted to $\mathrm{CO}_{2}$ ( $\mathrm{t} \mathrm{CO}_{2} \mathrm{e}$ ha) (using a carbon mass to $\mathrm{CO}_{2} \mathrm{e}$ multiple of 3.667), which was then multiplied by the average accumulation rate $\left(\mathrm{cm} \mathrm{yr}^{-1}\right)$ to produce the average $\mathrm{CO}_{2}$ accumulation rate $\left(\mathrm{t} \mathrm{CO}_{2} \mathrm{e} \mathrm{ha}^{-1} \mathrm{yr}^{-1}\right)$

Where $D$ is distance between date markers $(\mathrm{cm})$ and $T$ is time between date markers.

$$
C O_{2} A R=B D \times 0.51 \times 3.667 \times A R \times 100
$$


222 Where BD is Bulk Density $\left(\mathrm{g} \mathrm{cm}^{-3}\right)$

2.2 Estimates of contemporary rates of net ecosystem carbon balance in Sphagnum-

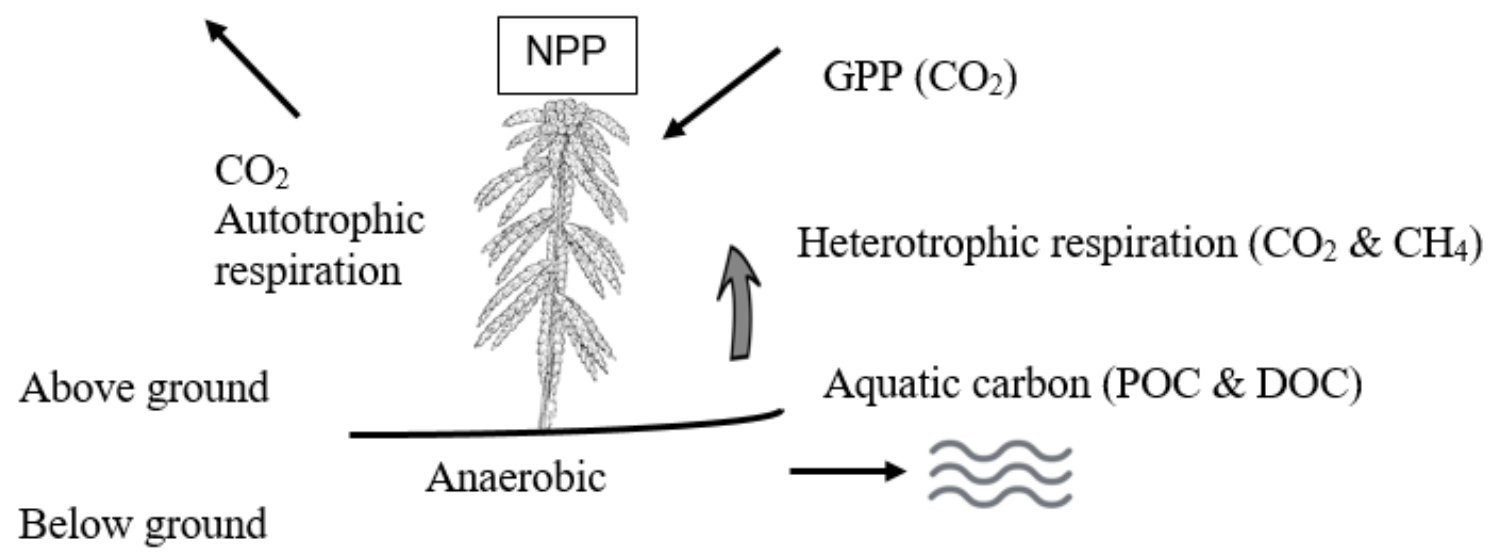

Autotrophic respiration
225

226

227

228

229

230

231

232

233

234

Fig. 2 Schematic representation of peatland carbon exchange. Net Primary Productivity $(N P P)=$ Gross Primary Productivity $(G P P)-$ Ecosystem Respiration $(E R) . E R=$ autotrophic respiration + heterotrophic aerobic respiration + heterotrophic anaerobic respiration.

Greenhouse gas (GHG) balance measurements, calculated for Fox Tor Mire, were used to produce a model for contemporary net ecosystem carbon balance (NECB). The NECB balance of a peat body is measured by quantifying the amount of gaseous and aquatic $\mathrm{C}$ gained or lost (fluxes) per surface unit area (Fig. 2). Values calculated for Sphagnum NPP were used as estimates of $\mathrm{CO}_{2} \mathrm{e}$ inputs in the peatland model. Export of carbon from the peatland model occurs via methane $\left(\mathrm{CH}_{4}\right)$ emissions and aquatic carbon pathways (Fig. 2).

\subsubsection{Model Formula}

Net ecosystem carbon balance NECB = NPP $\left(\mathrm{CO}_{2}\right.$ assimilation based on Sphagnum growth $)$ Carbon losses as aquatic DOC \& POC - carbon losses as $\mathrm{CH}_{4}$ and $\mathrm{CO}_{2} *$ 
* No measure was taken of direct losses of $\mathrm{CO}_{2}$ from the peat body resulting from aerobic heterotrophic respiration. Average values for ombrotrophic sites have been used from the literature to quantify potential losses from heterotrophic aerobic respiration (Section 4.4).

\subsubsection{Measurement of Sphagnum growth and net primary production}

242 Measures of annual increase in Sphagnum stem lengths, over a two year period, were used to 243 calculate NPP and provide estimates of present-day levels of $\mathrm{CO}_{2} \mathrm{e}$ sequestration. Single244 species stands of aquatic and terrestrial Sphagna were harvested from replicate $100 \mathrm{~cm}^{2}$

$245\left(1 \mathrm{dm}^{-2}\right)$ sample areas in December 2012 and 2013. The current year's annual growth was separated from the previous year's growth at the point of 'growth shut down', denoted by a kink in the stem and aggregation of stem branches (Clymo, 1970). Arising's were dried to constant mass, ground to a fine powder and the carbon content analysed in a CHN Elemental 249 Analyser (EA1110). Carbon density was derived by multiplying dry weight $\left(\mathrm{g} \mathrm{cm}^{-2}\right)$ by the carbon content measured for individual species samples. In addition, mean annual increase in stem length $\left(\mathrm{cm} \mathrm{yr}^{-1}\right)$ and mean stem density (number of capitula $\mathrm{dm}^{-2}$ ) was calculated and presented for each Sphagnum species.

\subsubsection{Export of aquatic carbon}

254 Continuous stream discharge flow rates were measured for the stream which drained the Fox Tor Mire Sphagnum and methane sample sites. Automated samples of drainage water were collected during the summer of 2011, under storm flow and base flow conditions to determine export of DOC and particulate organic carbon (POC). DOC was analysed using a multiplied by the associated stream discharge (Q) to provide continuous load data in $\mathrm{mg} \mathrm{s}^{-1}$. 
262 Summer values for continuous load were used to estimate annual load by multiplying mean 263 daily load by the annual discharge (Hope et al. 1994). Flux was calculated by dividing load 264 by the peatland area (58.3 ha), giving the flux as Total Organic Carbon (TOC).

\subsubsection{Methane emissions associated with Sphagnum-dominated microforms}

Methane emissions were collected over lawn, pond and hummock microforms, using static chambers, during the summers of 2014 and 2015. Chambers, consisting of transparent $4.5 \mathrm{~L}$ PET plastic demijohns with a footprint of $130 \mathrm{~mm}^{2}$ and a total headspace of ca. $4 \mathrm{~L}$ were levelled and inserted into the peat or water surface to a depth of $5 \mathrm{~cm}$ (Moore \& Roulet, 1991). Floatation aids were attached to the sides of the chambers that were to be placed in the

271 pool microform. Temperatures in the chamber headspace were not dissimilar to ambient 272 temperature, which ranged from $8-24^{\circ} \mathrm{C}$.

273 A total of 15 chambers were positioned, five replicates over each microform and weekly 274 samples taken. Chambers were fitted with sample points and extracted gas transferred to the 275 laboratory for analysis in sterile vacuum sample bags. Accumulated gas was analysed using a 276 Bruker IFS-66 spectrometer and Fourier Transform Infrared (FT-IR) analysis (as described 277 by Christian et al, 2014). Outputs from the FT-IR were calibrated using a series of known concentrations of $\mathrm{CH}_{4}$. Methane values were converted from a volume to a mass using the Ideal Gas Law PV = nRT; where $\mathrm{P}=$ atmospheric pressure $(\mathrm{Pa}), \mathrm{V}=$ volume $\left(\mathrm{m}^{3}\right), \mathrm{n}=$ molar mass $\left(\mathrm{g} \mathrm{mol}^{-1}\right), \mathrm{R}$ is the ideal gas constant $\left(\mathrm{m}^{3} \mathrm{~Pa} \mathrm{~K}^{-1} \mathrm{~mol}^{-1}\right)$, and $\mathrm{T}=$ temperature of the gas

281 (K). $\mathrm{CH}_{4}$ fluxes were converted to $\mathrm{CO}_{2}$ equivalent values $\left(\mathrm{t}_{2} \mathrm{e} \mathrm{ha}^{-1} \mathrm{yr}^{-1}\right)$ using a global 
284 All statistical comparison $(P \leq 0.05)$ of rates of carbon sequestration between sites and 285 between past and contemporary periods were evaluated using Kruskal-Wallis and Mann-

286 Whitney $U$-tests. Site measures of central tendency and variation are reported as mean \pm 287 standard error (SE) with replicate numbers (n) unless otherwise indicated.

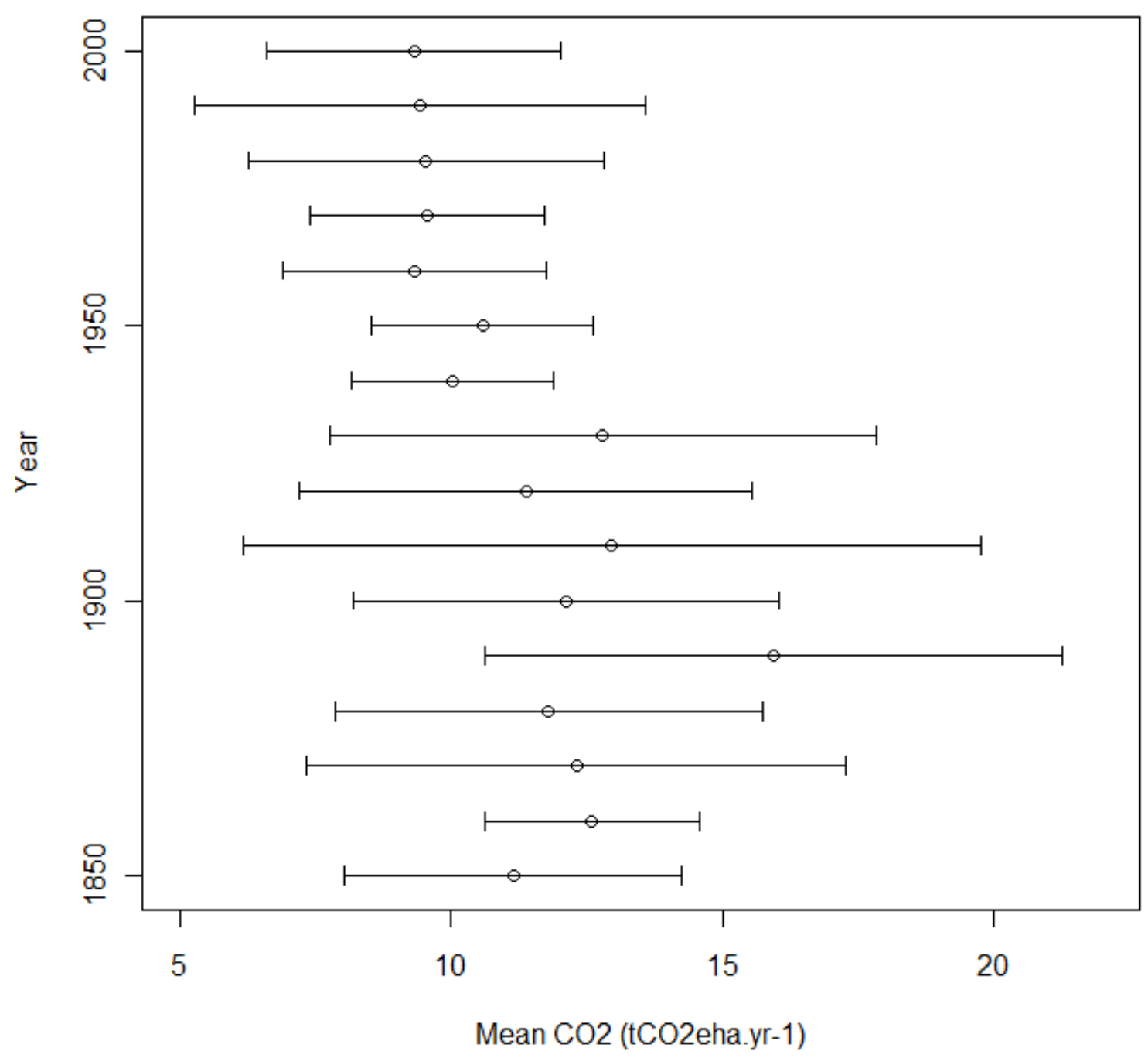


292 Fig. 3 Past rates of carbon accumulation (expressed as $\left.\mathrm{CO}_{2} \mathrm{e}\right)$ at the valley mire site (18502010). Data were obtained from Fox Tor Mire, Dartmoor, via sequential analyses of carbon densities in peat core segments dated using SCP techniques. Values represent the means of three cores taken in 2011. Error bars represent \pm 1 standard deviation.

297 Mean rates of $\mathrm{CO}_{2}$ accumulation in the valley mire (Fig. 3) appear stable around $12 \mathrm{t} \mathrm{CO}_{2} \mathrm{e}$ $\mathrm{ha}^{-1} \mathrm{yr}^{-1}$ until 1930. Fig. 3 shows a step change in the mean rate of $\mathrm{CO}_{2}$ sequestration from 1940 onwards, with a decrease to a mean of less than $10 \mathrm{t} \mathrm{CO}_{2} \mathrm{e} \mathrm{ha}^{-1} \mathrm{yr}^{-1}$. There is a large variability around the means, particularly in the late 1800 s and early 1900 s with maximum values for $\mathrm{CO}_{2}$ sequestration of $21.6 \mathrm{t} \mathrm{CO}_{2} \mathrm{e} \mathrm{ha}^{-1} \mathrm{yr}^{-1}$ and minimum values of $5.7 \mathrm{t} \mathrm{CO}_{2} \mathrm{e} \mathrm{ha}^{-1} \mathrm{yr}^{-1}$. The alluvial marker showed mean depths of peat of $127.5 \mathrm{~cm}$ and rates of peat accumulation of $9.51 \mathrm{~mm} \pm 2 \mathrm{~mm} \mathrm{yr}^{-1}$ (Table 1). This rate was broadly in agreement higher than rates for valley mire in the published literature (Gorham, 1991; Barber et al. 1994; Tallis, 1998). Bulk density was comparatively low at $0.079 \pm 0.004 \mathrm{~g} \mathrm{~cm}^{-3}$ dry matter (Table 1), compared to values published in the literature. valley mire (1876-2010). Estimates were based on an alluvial clay marker dated to 1876.

311 Values represent the means of 20 cores at all depths. Values \pm mean show standard error.

\begin{tabular}{|c|c|c|c|c|c|}
\hline $\begin{array}{l}\text { Number } \\
\text { of peat } \\
\text { cores }\end{array}$ & $\begin{array}{l}\text { Rate of peat } \\
\text { accumulation } \\
\left(\mathrm{mm} \mathrm{yr}^{-1}\right)\end{array}$ & $\begin{array}{l}\text { Bulk density } \\
\text { of peat } \\
\left(\mathrm{g} \mathrm{cm}^{-3}\right)\end{array}$ & $\begin{array}{l}\text { Ash-free } \\
\text { carbon } \\
\text { content (\%) }\end{array}$ & $\begin{array}{l}\text { Carbon } \\
\text { accumulation } \\
\text { (t C } \\
\mathrm{ha}^{-1} \mathrm{yr}^{-1} \text { ) }\end{array}$ & $\begin{array}{l}\mathrm{CO}_{2} \\
\text { sequestration } \\
\left(\mathrm{t} \mathrm{CO}_{2} \mathrm{e} \mathrm{ha}^{-1}\right. \\
\left.\mathrm{yr}^{-1}\right)\end{array}$ \\
\hline 20 & $9.51 \pm 2$ & $0.079 \pm 0.004$ & $51 \pm 3.49$ & $3.61 \pm 0.45$ & $13.23 \pm 1.64$ \\
\hline
\end{tabular}


313 Using the mean accumulation rate of $11.26 \mathrm{t} \pm 0.68 \mathrm{t} \mathrm{CO}_{2} \mathrm{e} \mathrm{ha}^{-1} \mathrm{yr}^{-1}\left(307 \mathrm{~g} \mathrm{C} \mathrm{m}^{-2} \mathrm{yr}^{-1}\right)$,

314 calculated using the SCP method, (Fig. 3), we can estimate that 88,000 tonnes of $\mathrm{CO}_{2}$ have

315 been sequestered in the valley mire over the 134 years (1876-2010) https://plymu.ni/peat-

316 animation .

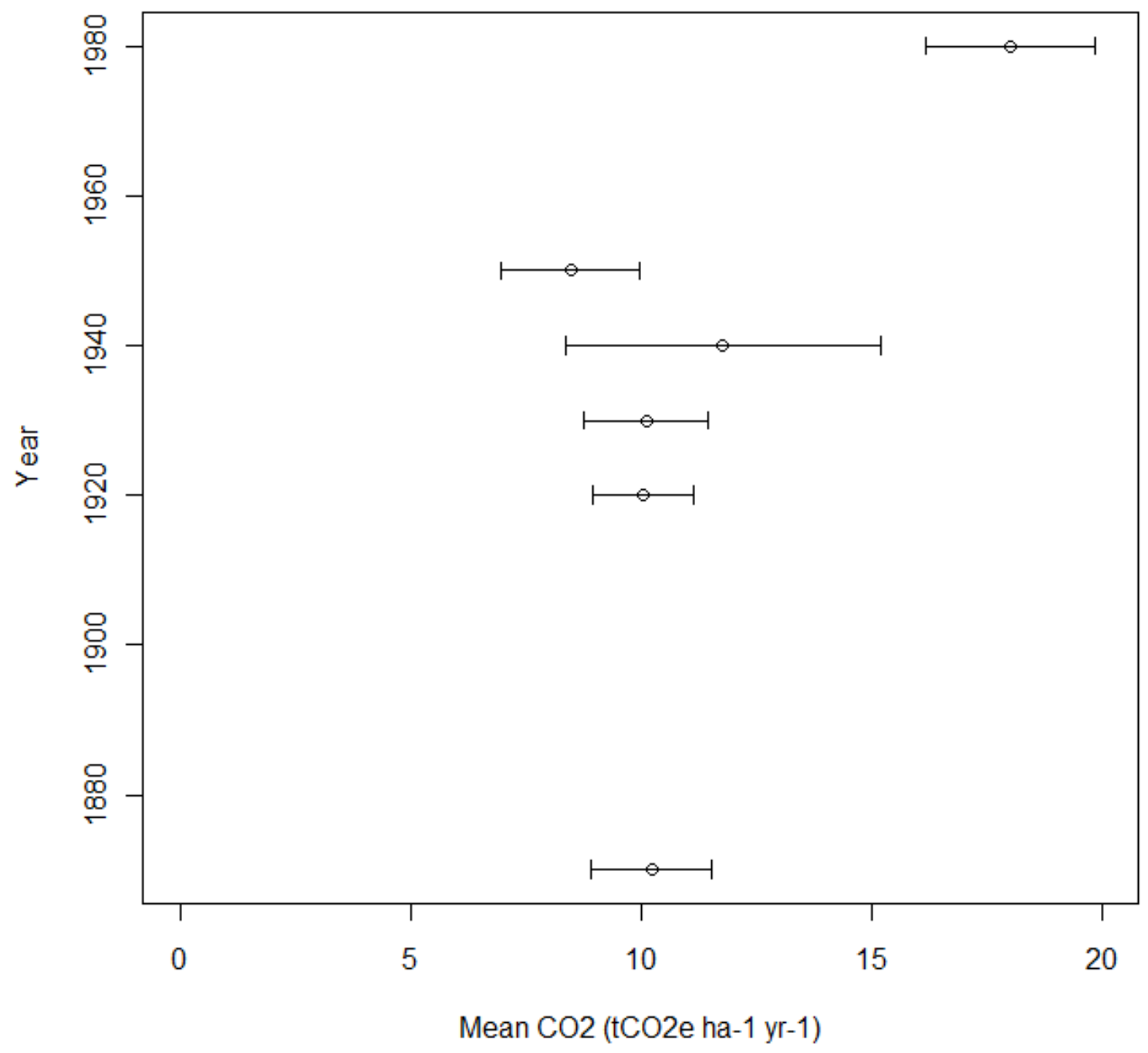

318 Fig. 4 Past rates of carbon accumulation (expressed as $\mathrm{CO}_{2} \mathrm{e}$ ) at the blanket bog site (18503191980 AD). Data were obtained from Red Lake Mire, Dartmoor, via sequential analyses of carbon densities in peat core segments dated using SCP techniques. Values represent the

321 means of four cores taken in 2011. Error bars represent \pm 1 standard deviation. 
322 Rates of $\mathrm{CO}_{2}$ sequestration in blanket bog ranged from 7.3 to $19.2 \mathrm{t} \mathrm{CO}_{2} \mathrm{e} \mathrm{ha}^{-1} \mathrm{yr}^{-1}$ (Fig. 4).

323 Mean values of $\sim 10 \mathrm{t} \mathrm{CO}_{2} \mathrm{e} \mathrm{ha}^{-1} \mathrm{yr}^{-1}$ occur until 1950. The most recent record from 1980

324 showed an apparent increase to $18 \mathrm{t} \mathrm{CO}_{2} \mathrm{e} \mathrm{ha}^{-1} \mathrm{yr}^{-1}$. Rose and Appleby (2005) acknowledge

325 that SCP dating methods are only accurate to within 15 years of the actual date. Any error

326 could be further compounded in the surface peat layers, where there is greater physical

327 difficulty in obtaining intact cores, due to the abundance of Eriophorum roots.

328 Table 2 Mean rates of peat accumulation and $\mathrm{CO}_{2}$ sequestration (1850-2010) in blanket bog 329 dated using the spheroidal carbonaceous particle (SCP) method. Values \pm mean show 330 standard error.

\begin{tabular}{|l|c|c|c|c|c|}
\hline & Core 1 & Core 2 & Core 3 & Core 4 & Mean \\
\hline $\begin{array}{l}\text { Peat } \\
\text { accumulation } \\
\mathrm{mm} \mathrm{yr}^{-1}\end{array}$ & 6.83 & 6.97 & 6.97 & 5.7 & $\mathbf{6 . 6 2} \pm \mathbf{0 . 3 1}$ \\
\hline $\begin{array}{l}\mathrm{CO}_{2} \\
\text { sequestration } \\
\mathrm{t} \mathrm{CO}_{2} \mathrm{e} \mathrm{ha-1} \mathrm{yr}^{-1}\end{array}$ & $11.92 \pm 1.69$ & $11.72 \pm 2.26$ & $11.74 \pm 2.4$ & $11.74 \pm 1.79$ & $\mathbf{1 1 . 7 7 \pm \mathbf { 0 . 8 8 }}$ \\
\hline
\end{tabular}

331 Mean rates of peat accumulation (Table 1) were significantly higher $\left(9.51 \pm 2 \mathrm{~mm} \mathrm{yr}^{-1}\right)$ in the

332 less consolidated valley mire peat compared to values shown in Table 2, for the higher

333 density blanket bog peat cores $\left(6.62 \mathrm{~mm} \pm 0.31 \mathrm{~mm} \mathrm{yr}^{-1}\right)$. However, means rate of $\mathrm{CO}_{2}$

334 sequestration for valley mire (Table 1$)$ and blanket bog were not significantly different $(P \leqslant$ $3350.05)$.

$336 \quad 3.2$ Net primary productivity of Sphagnum species on blanket bog and valley mire sites

337 Table 3 Capitulum density and annual increase in stem length for four Sphagnum species on

338 Dartmoor. Samples were collected from blanket bog and valley mire sites in the Decembers 
of 2012 and 2013. Values following the means shown as \pm denote standard error. Values with different letters differ significantly $(P \leq 0.05)$. Differences of variables were analysed with

341 the Kruskal Wallis test and a multiple comparison test after Siegel \& Castellan (1988).

\begin{tabular}{|l|c|c|c|c|}
\hline & $\begin{array}{l}\text { Sphagnum } \\
\text { cuspidatum }\end{array}$ & $\begin{array}{l}\text { Sphagnum } \\
\text { denticulatum }\end{array}$ & $\begin{array}{l}\text { Sphagnum } \\
\text { papillosum }\end{array}$ & $\begin{array}{l}\text { Sphagnum } \\
\text { capillifolium } \\
\text { var. rubellum }\end{array}$ \\
\hline $\begin{array}{l}\text { Number of } \\
\text { replicate sample } \\
\text { plots }\left(\mathrm{dm}^{-2}\right)\end{array}$ & 26 & 26 & 26 & 26 \\
\hline $\begin{array}{l}\text { Mean density of } \\
\text { capitulum } \\
\left(\mathrm{dm}{ }^{-1}\right)\end{array}$ & $103 \pm 9.8 \mathrm{~b}$ & $60 \pm 6.2 \mathrm{a}$ & $105 \pm 11.1 \mathrm{~b}$ & $117 \pm 19.2 \mathrm{~b}$ \\
\hline $\begin{array}{l}\text { Number of stem } \\
\text { measurements }\end{array}$ & 272 & 272 & 272 & 272 \\
\hline $\begin{array}{l}\text { Mean annual } \\
\text { growth of stem }_{\left(\mathrm{cm} \text { yr }^{-1} \text { ) }\right.}\end{array}$ & $6.9 \pm 0.22 \mathrm{~b}$ & $5.5 \pm 0.11 \mathrm{a}$ & $7.35 \pm 0.17 \mathrm{c}$ & $6.85 \pm 0.37 \mathrm{~b}$ \\
\hline
\end{tabular}

342

343 Sphagnum capillifolium var. rubellum had the highest capitulum density followed by $S$.

344 papillosum and S. cuspidatum (Table 3). S. denticulatum was found to have a significantly $(P$

$345 \leqslant 0.05)$ lower capitulum density when compared with the three other species. S. papillosum

346 had the highest annual increase in length of $7.35 \mathrm{~cm} \pm 0.17 \mathrm{~cm} \mathrm{yr}^{-1}$, which was significantly

347 greater than the three other species. Krebs et al. (2016) reported that globally rates of growth

348 of S. papillosum range from $0.4 \mathrm{~cm}$ to $4.6 \mathrm{~cm} \mathrm{yr}^{-1}$, with mean capitulum density ranging from

$349125 \mathrm{dm}^{-2}$ to $175 \mathrm{dm}^{-2}$. In Georgia, Black Sea, Krebs et al. (2016) found a mean increase in

350 stem length of $5 \mathrm{~cm} \mathrm{yr}^{-1}$ for $S$. papillosum with a range from $2.3 \mathrm{~cm} \pm 1.3 \mathrm{~cm}$ to

$351 \quad 10.2 \mathrm{~cm} \pm 3.0 \mathrm{~cm} \mathrm{yr}^{-1}$ and significantly higher mean values of over $12 \mathrm{~cm} \mathrm{yr}^{-1}$ for $S$. palustre. 


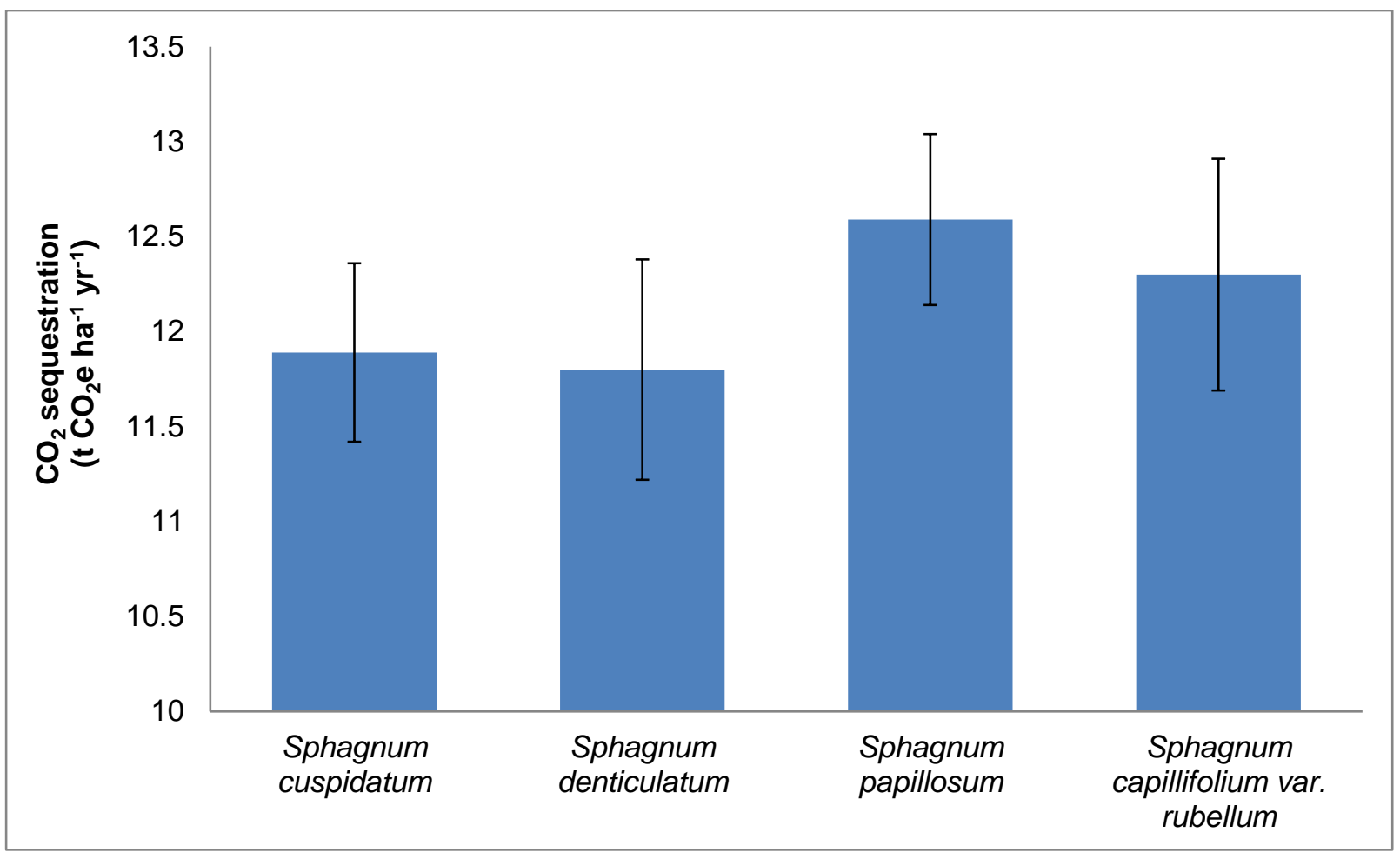

353 Fig. 5 Mean rates of net primary productivity of four Sphagnum species on Dartmoor, during 2012 and 2013. Samples were collected from blanket bog and valley mire sites in the Decembers of 2012 and 2013 and are based on 1 year's growth. Bars show standard error plus and minus the mean. Values represent the means for replicated sample plots $\left(d m^{2}\right) ; S$. cuspidatum $n=25$, S. denticulatum $n=10$, S. papillosum $n=24$ and S. capillifolium var. rubellum $n=15$. No significant differences $(P \leq 0.05)$ were found in NPP between the four species, using the Kruskal Wallis test.

Fig. 5 shows that $S$. papillosum had the highest NPP $\left(12.59 \mathrm{t} \pm 0.45 \mathrm{t} \mathrm{CO}_{2} \mathrm{e} \mathrm{ha}^{-1} \mathrm{yr}^{-1}\right)$, followed by $S$. capillifolium var. rubellum $\left(12.3 \mathrm{t} \pm 0.61 \mathrm{t} \mathrm{CO}_{2} \mathrm{e} \mathrm{ha}^{-1} \mathrm{yr}^{-1}\right)$ and, the aquatic Sphagna: S. cuspidatum $\left(11.89 \mathrm{t} \pm 0.47 \mathrm{t} \mathrm{CO}_{2} \mathrm{e} \mathrm{ha}^{-1} \mathrm{yr}^{-1}\right)$ and $S$. denticulatum $(11.8 \mathrm{t} \pm 0.58 \mathrm{t}$

$\left.363 \mathrm{CO}_{2} \mathrm{e} \mathrm{ha}^{-1} \mathrm{yr}^{-1}\right)$. Rates were not found to be significantly different at $P \leqslant 0.05$. Higher rates 364 of NPP were found for S. papillosum $\left(16.11 \mathrm{t} \pm 0.45 \mathrm{t} \mathrm{CO}_{2} \mathrm{e} \mathrm{ha} \mathrm{hr}^{-1}\right)$ in the lawn microform 365 compared with $S$. papillosum in hummock microform $\left(9.06 \mathrm{t} \mathrm{CO}_{2} \mathrm{e} \mathrm{ha}^{-1} \mathrm{yr}^{-1}\right)$. 


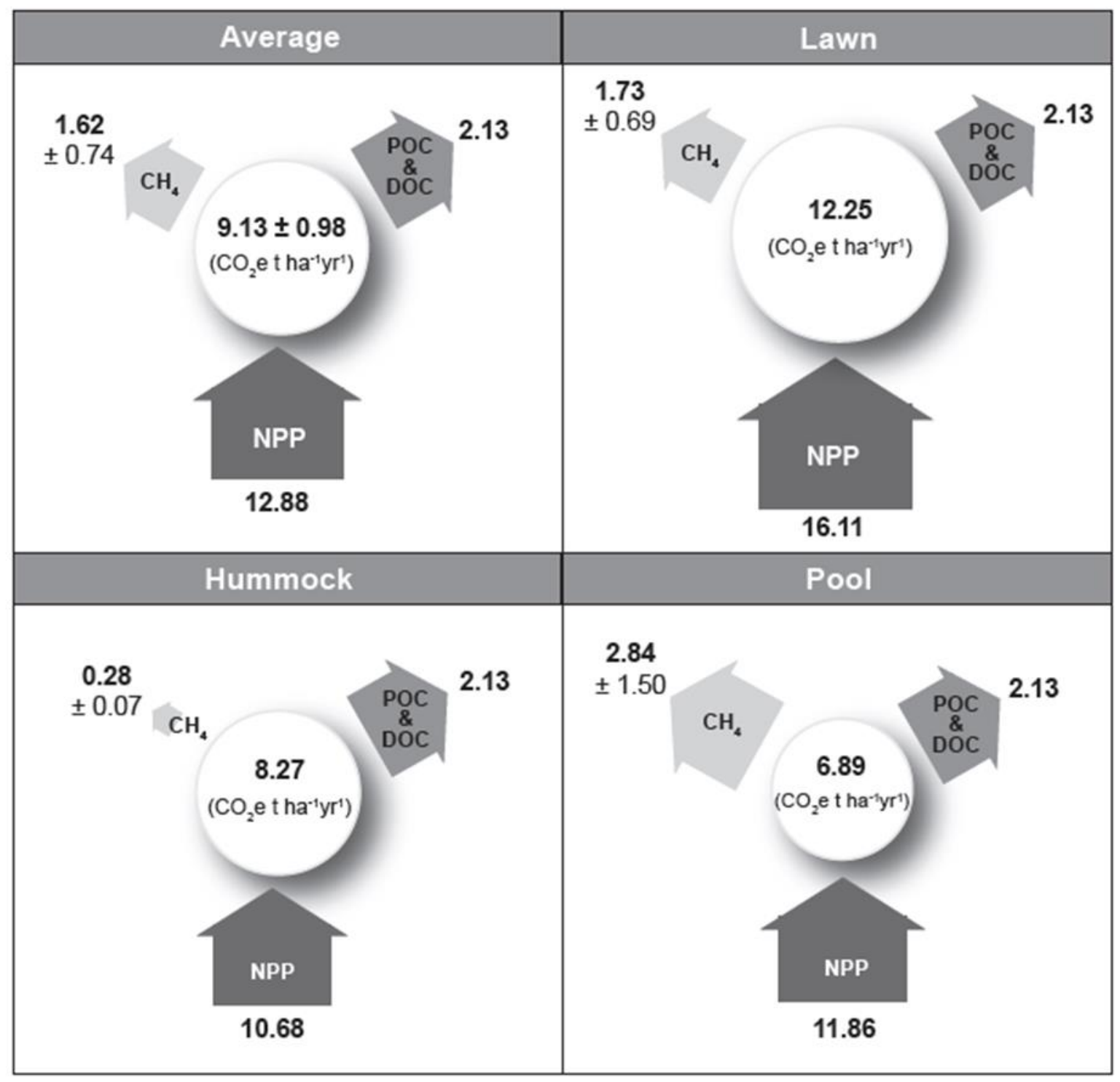

368 Fig. 6 Net ecosystem carbon balance for three peatland microforms (2011-2015). All values

369 are in $t \mathrm{CO}_{2} e \mathrm{ha}^{-1} \mathrm{yr}^{l}$. Net primary productivity (NPP) of the Sphagnum species from each

370 microform were calculated from annual stem increment data. Mean NPP of Sphagnum

371 capillifollium var. rubellum (12.3 $\left.t \pm 0.61 t \mathrm{CO}_{2} e \mathrm{ha}^{-1} \mathrm{yr}^{-1}\right)$ and Sphagnum papillosum

372 (9.06 t $\left.\mathrm{CO}_{2} e \mathrm{ha}^{-1} \mathrm{yr}^{1}\right)$ for hummock microforms; Sphagnum papillosum

373 (16.11 t \pm 0.45 t $\left.\mathrm{CO}_{2 e} \mathrm{ha}^{-1} \mathrm{yr}^{1}\right)$ for lawn microforms; and Sphagnum cuspidatum

$374\left(11.89 t \pm 0.47 t \mathrm{CO}_{2} e \mathrm{ha}^{-1} \mathrm{yr}^{-1}\right)$ and Sphagnum denticulatum $\left(11.8 \mathrm{t} \pm 0.58 t \mathrm{CO}_{2} \mathrm{ha}^{-1} \mathrm{yr}^{-1}\right)$ 
375 for pool microforms. Aquatic loss of carbon of 2.13 t $\mathrm{CO}_{2} e \mathrm{ha}^{-1} \mathrm{yr}^{-1}$ was calculated from

376

377

378

379

380

381

382

383

384

385

386

387

388

389

390

391

392

393

394

395

396

397

annual export of $\mathrm{POC}$ and DOC estimated for the entire peat body. $\mathrm{CH}_{4}$ emissions were

monitored for microforms during 2014 and 2015 and converted to $\mathrm{CO}_{2}$. $\mathrm{CO}_{2}$ e losses from

$\mathrm{CH}_{4}, \mathrm{POC}$ and DOC were subtracted from $\mathrm{NPPCO} \mathrm{CO}_{2}$ inputs to give NECB values.

The values in the central circles of the NECB model (Fig. 6) show that all three of the Sphagnum-dominated microforms in the valley mire were significant sinks for $\mathrm{CO}_{2}$ during the study period, with mean sequestration rates of $9.13 \mathrm{t} \pm 0.98 \mathrm{t} \mathrm{CO}_{2} \mathrm{e} \mathrm{ha} \mathrm{hr}^{-1} \mathrm{yr}^{-1}(249 \mathrm{~g} \mathrm{C}$ $\mathrm{m}^{-2} \mathrm{yr}^{-1}$ ). The lawn microform was found to be the largest sink for $\mathrm{CO}_{2}$, followed by the hummock and pool microforms, due largely to higher rates of Sphagnum NPP (Fig. 6).

Average summer $\mathrm{CH}_{4}$ emissions were highest for the pool microform,

$2.84 \mathrm{t} \pm 1.5 \mathrm{t} \mathrm{CO}_{2} \mathrm{e} \mathrm{ha}^{-1} \mathrm{yr}^{-1}$, and lowest for the hummock microform,

$0.28 \mathrm{t} \pm 0.07 \mathrm{t} \mathrm{CO}_{2} \mathrm{e} \mathrm{ha}{ }^{-1} \mathrm{yr}^{-1}$; the lawn microform had intermediate losses of $\mathrm{CH}_{4}$ at $1.73 \mathrm{t} \pm 0.69 \mathrm{t} \mathrm{CO}_{2} \mathrm{e} \mathrm{ha}^{-1} \mathrm{yr}^{-1}$.

\subsection{Discussion}

\subsection{Past rates of peat accumulation}

Actively growing peatlands sequester carbon, accumulating organic mass as the excess of vegetation production over decay. In temperate peatlands, peat accumulation rates vary according to differences in growing season, depth of oxygen diffusion, microform and plant species composition (Clymo, 1984; Tallis, 1998; Charman, 2002; Ukonmaanaho et al. 2006; Chambers et al. 2011). Our study suggests that since the industrial revolution (1850), rates of peat accumulation averaged $9.51 \mathrm{~mm} \pm 2 \mathrm{~mm} \mathrm{yr}^{-1}$ for valley mire (Table 1) and $6.62 \mathrm{~mm} \pm 0.31 \mathrm{~mm} \mathrm{yr}^{-1}$ for blanket bog (Table 2). These rates far exceed the average historical rates described for more northerly, boreal and continental peatlands (Gorham, 1991; Clymo et al. 1998; Tallis, 1998; Roulet et al. 2007). Higher values were estimated by 
399 Botch and Masing (1983) of up to $3 \mathrm{~mm} \mathrm{yr}^{-1}$ for boreal mires and $30.3 \mathrm{~mm} \mathrm{yr}^{-1}$ for lowland 400 warm and humid mires in Georgia, Black Sea (Krebs et al. 2016). Long-term records for 401 temperate systems suggest an average peat accumulation of $0.2-1 \mathrm{~mm} \mathrm{yr}^{-1}$ (Aaby \& Tauber, 402 1975), with blanket bogs reported as having a large range 0.1-1.2 $\mathrm{mm} \mathrm{yr}^{-1}$ (Tallis, 1998) and 403 raised mires at rates of $0.5-1 \mathrm{~mm} \mathrm{yr}^{-1}$ (Charman, 2002; Roulet et al. 2007). The surface 404 profile and vegetation composition of mires are in a constant state of change as shifts in peat accumulation rates are influenced by various factors, including changes in climate (Clymo \& Pearce, 1995). Vegetation on the peat surface may show poor affiliation with depth of peat . Under natural conditions, acrotelm peat layers tend to show higher rates of carbon

408 accumulation than the catotelm layers. This may arise because the fresh peat at the base of the acrotelm is still subject to occasional aerobic decomposition, or because of differences in vegetation composition in the past, or because there have been periods in the past when conditions were sub-optimal for peat formation (Charman, 2002; Holden et al. 2007; Lindsay, 2010; Charman et al. 2013).

\section{$413 \quad 4.2$ Comparison of past rates of carbon accumulation}

414 Our calculations of past (1850-2010) rates of carbon accumulation in temperate mires show 415 similar rates for valley mire, $11.26 \mathrm{t} \pm 0.68 \mathrm{t} \mathrm{CO}_{2} \mathrm{e} \mathrm{ha}^{-1} \mathrm{yr}^{-1}\left(307 \mathrm{~g} \mathrm{C} \mathrm{m}^{-2} \mathrm{yr}^{-1}\right)$ (Fig. 3) and blanket bog, $11.77 \mathrm{t} \pm 0.88 \mathrm{t} \mathrm{CO}_{2} \mathrm{e} \mathrm{ha}^{-1} \mathrm{yr}^{-1}\left(321 \mathrm{~g} \mathrm{C} \mathrm{m}^{-2} \mathrm{yr}^{-1}\right)$ (Table 2). When compared to

$417 \mathrm{CO}_{2}$ sequestration recorded for boreal and high latitude northern peatlands (Gorham, 1991;

418 Vitt et al. 2000; Turunen et al. 2002), our rates are at the upper limits of those recorded.

419 According to Roulet et al. (2007) the rate of C accumulation in northern peatlands, over the last 6-8 thousand years, is estimated to be $0.73-1.1 \mathrm{t} \mathrm{CO}_{2} \mathrm{e} \mathrm{ha}^{-1} \mathrm{yr}^{-1}\left(20-30 \mathrm{~g} \mathrm{C} \mathrm{m}^{-2} \mathrm{yr}^{-1}\right)$, with $\mathrm{CO}_{2}$ sequestration rates for two peat cores in Ontario, Canada for the time interval 
$<1 \mathrm{t} \mathrm{CO}_{2} \mathrm{e} \mathrm{ha}^{-1} \mathrm{yr}^{-1}$, are typically reported for long-term peat records in northern and boreal 424 peatlands.

425 Utstøl-Klein et al. (2015) reported peat growth and C accumulation for 1978-1995 of $4268.38 \mathrm{t} \mathrm{CO}_{2} \mathrm{e} \mathrm{ha}^{-1} \mathrm{yr}^{-1}\left(230 \mathrm{~g} \mathrm{C} \mathrm{m}^{-2} \mathrm{yr}^{-1}\right)$ and for $1995-2012$ of $13.56 \mathrm{t} \mathrm{CO}_{2} \mathrm{e} \mathrm{ha}^{-1} \mathrm{yr}^{-1}\left(370 \mathrm{~g} \mathrm{C}^{-}\right.$ 427 $\mathrm{m}^{-2} \mathrm{yr}^{-1}$ ) in Sphagnum-dominated boreal peatland in south-east Norway. These values are similar to those reported for contemporary $\mathrm{CO}_{2}$ sequestration in our study. Utstøl-Klein et al. (2015) and Helfter et al. (2015) suggested that higher rates of C accumulation were associated with increased precipitation. McNeil and Waddington (2003) concluded that Sphagnum photosynthesis was greatest at wetter sites and that drying and wetting cycles negatively affect Sphagnum NPP and net ecosystem $\mathrm{CO}_{2}$ exchange.

\subsection{Net Primary Productivity (NPP) of Sphagnum}

Fig. 5 shows that present-day mean rates of Sphagnum NPP for the southern moors ranged from $11.8 \mathrm{t} \pm 0.58 \mathrm{t} \mathrm{CO}_{2} \mathrm{e} \mathrm{ha}^{-1} \mathrm{yr}^{-1}$ for the aquatic species, Sphagnum denticulatum, to $12.59 \mathrm{t} \pm 0.45 \mathrm{t} \mathrm{CO}_{2} \mathrm{e} \mathrm{ha}^{-1} \mathrm{yr}^{-1}$ for the lawn species, Sphagnum papillosum, with Sphagnum capillifolium var. rubellum $\left(12.3 \mathrm{t} \pm 0.61 \mathrm{t} \mathrm{CO}_{2} \mathrm{e} \mathrm{ha}^{-1} \mathrm{yr}^{-1}\right)$ and Sphagnum cuspidatum

438 (11.89 $\left.\mathrm{t} \pm 0.47 \mathrm{t} \mathrm{CO}_{2} \mathrm{e} \mathrm{ha}^{-1} \mathrm{yr}^{-1}\right)$ intermediate. These rates for contemporary NPP are similar to past rates of carbon accumulation occurring on site during the last 160 years. Krebs et al. 440 (2016) reported mean global NPP of S. papillosum to be $3.81 \mathrm{t} \mathrm{CO}_{2} \mathrm{e} \mathrm{ha}^{-1} \mathrm{yr}^{-1}(204 \mathrm{~g}$ dry 441 weight $\left.\mathrm{m}^{-2} \mathrm{yr}^{-1}\right)$ with a range of $0.54-9.15 \mathrm{t} \mathrm{CO}_{2} \mathrm{e} \mathrm{ha}^{-1} \mathrm{yr}^{-1}\left(29-490 \mathrm{~g}\right.$ dry weight $\left.\mathrm{m}^{-2} \mathrm{yr}^{-1}\right)$.

442 Gunnarsson (2005) suggested a mean global NPP for Sphagnum of 3.74-5.6 t CO $\mathrm{e} \mathrm{ha}^{-1} \mathrm{yr}^{-1}$ 443 (2-3 t dry weight $\left.\mathrm{m}^{-2} \mathrm{yr}^{-1}\right)$. Krebs et al. (2016) recorded the highest Sphagna productivity in 444 warm and humid peatlands in southern Georgia, Black Sea, with NPP for S. papillosum of $445 \quad 5.03-10.24 \mathrm{t} \mathrm{CO}_{2} \mathrm{e} \mathrm{ha}^{-1} \mathrm{yr}^{-1}\left(269-548 \mathrm{~g}^{-1}\right.$ dry weight $\left.\mathrm{m}^{-2} \mathrm{yr}^{-1}\right)$ and for S. palustre of 7.23$44614.72 \mathrm{t} \mathrm{CO}_{2} \mathrm{e} \mathrm{ha}^{-1} \mathrm{yr}^{-1}$ (387-788 $\mathrm{g}_{\text {dry }}$ weight $\left.\mathrm{m}^{-2} \mathrm{yr}^{-1}\right)$; rates closer to our NPP values for $S$. 
papillosum. Lütt (1992) reported $\mathrm{CO}_{2}$ sequestration rates of 3.21-4.11 t CO $2 \mathrm{e} \mathrm{ha}^{-1} \mathrm{yr}^{-1}(172-$

$448220 \mathrm{~g}$ dry weight $\mathrm{m}^{-2} \mathrm{yr}^{-1}$ ) for S. papillosum in northern Germany, at similar latitudes to the

449 UK but with a less favourable continental climate. In the UK, Clymo (1970) reported values

450 of $11.4 \mathrm{t} \mathrm{CO}_{2} \mathrm{e} \mathrm{ha}^{-1} \mathrm{yr}^{-1}\left(610 \mathrm{~g}\right.$ dry weight $\left.\mathrm{m}^{-2} \mathrm{yr}^{-1}\right)$ for transplanted Sphagnum. There is a

451 great deal of variability in the literature reflecting local growth conditions (Gunnarson, 2005;

452 Loisel et al. 2012; Campbell, 2014; Nijp et al. 2015; Krebs et al. 2016), the methodology

453 used and difficulty in assessing annual increases in Sphagnum growth (Clymo, 1970).

454 However, our mean values for Sphagnum NPP are over twice those of global means reported

455 by Gunnarsson (2005) and suggest that means reported from the literature may well provide

456 an underestimate of contemporary rates of carbon sequestration occurring under optimal

457 conditions in temperate peatlands. Similar values of $8.58 \mathrm{t} \mathrm{CO}_{2} \mathrm{e} \mathrm{ha} \mathrm{hr}^{-1} \mathrm{yr}^{-1}\left(234 \mathrm{~g} \mathrm{C} \mathrm{m}^{-2} \mathrm{y}^{-1}\right)$

458 have been reported for a raised bog in New Zealand (Campbell et al. 2014), ascribed to the

459 mild climate and long growing season at temperate sites, showing the sensitivity of

460 ombrotrophic peat growth to climatic conditions.

\section{$461 \quad 4.4$ Net Ecosystem Carbon Balance (NECB)}

462 Mean contemporary $\mathrm{CO}_{2}$ sequestration rates for Sphagna in the valley mire were calculated to 463 be $9.13 \mathrm{t} \pm 0.98 \mathrm{t} \mathrm{CO}_{2} \mathrm{e} \mathrm{ha}^{-1} \mathrm{yr}^{-1}$ from the NECB model (Fig. 6). This value does not take into 464 account aerobic heterotrophic respiration. Ecosystem respiration is one of the major fluxes in 465 peatland net ecosystem $\mathrm{CO}_{2}$ exchange (composed of autotrophic + heterotrophic respiration), comprising of up to $80 \%$ of exchange (Riutta et al. 2007; Wilson et al. 2016; Kandel et al. 2018). By not accounting for the aerobic heterotrophic component of respiration in our model,

468 the calculated value of $9.13 \mathrm{t} \pm 0.98 \mathrm{t} \mathrm{CO}_{2} \mathrm{e} \mathrm{ha}^{-1} \mathrm{yr}^{-1}$ is likely to be the maximum value for the 469 contribution of carbon sequestration to long-term carbon storage. Taking an upper estimate for 470 aerobic respiration from the literature of $50 \%$ of heterotrophic respiration (Riutta et al. 2007; 
471 Laine et al. 2009; Minke et al. 2016; Wilson et al. 2016), it is possible that $3.65 \mathrm{t} \mathrm{CO}_{2} \mathrm{e} \mathrm{ha}^{-1} \mathrm{yr}^{-}$

$472^{1}(40 \%$ of annual NPP) could be lost from the acrotelm via aerobic heterotrophic microbial

473 decomposition. This would leave a minimum contribution of $5.48 \mathrm{t} \mathrm{CO}_{2} \mathrm{e} \mathrm{ha}^{-1} \mathrm{yr}^{-1}$. However,

474 values at the lower end of the range $9.13-5.48 \mathrm{t} \mathrm{CO}_{2} \mathrm{e} \mathrm{ha}^{-1} \mathrm{yr}^{-1}$, are unlikely in the pool and

475 lawn microforms, where levels of aerobic heterotrophic respiration will be low in the 476 permanently saturated conditions (Laine et al. 2009; Wilson et al. 2016). Wilson et al. (2016)

477 found considerable spatial and temporal variation in the annual NECB with the highest uptake 478 observed in Eriophorum angustifolium dominated intact sites in $2009\left(6.25 \mathrm{t} \mathrm{CO}_{2}-\mathrm{eq} \mathrm{ha}^{-1} \mathrm{yr}^{-1}\right)$.

479 Vegetation at the Fox Tor valley mire site consisted of a mosaic of mire communities including 480 Eriophorum sp., other Cyperaceae and dwarf shrub species. As reported by Wilson et al. (2016) many of these vascular plant species have higher growth rates than Sphagna and where present with Sphagnum mosses are likely to lead to increased overall NPP.

NECB and its components in peatlands are known to vary considerably between sites (Limpens et al. 2008; Lund et al. 2009), as well as inter-annually within sites. During a twoyear study of NECB in an intact low-lying ombrotrophic mire in Scotland, Dinsmore et al. 486 (2010) found that the peatland acted as a net $\mathrm{CO}_{2} \mathrm{e}$ sink of $3.52 \mathrm{t} \mathrm{CO}_{2} \mathrm{e} \mathrm{ha}^{-1} \mathrm{yr}^{-1}$. Run-off of 487 DOC was found to be the principal route for loss of carbon, accounting for $24 \%$ of the uptake via NECB, with an estimated $12 \%$ evasion of carbon from the stream surface. Gaseous emissions of $\mathrm{CH}_{4}$ and $\mathrm{N}_{2} \mathrm{O}$ combined returned $4 \%$ of $\mathrm{CO}_{2} \mathrm{e}$. In our study the valley mire peatland acted as a carbon sink with a mean for peatland microforms of $9.13 \mathrm{t} \pm 0.98 \mathrm{t} \mathrm{CO}_{2} \mathrm{e}$ $491 \mathrm{ha}^{-1} \mathrm{yr}^{-1}$ (Fig. 6). This value was over twice that recorded by Dinsmore et al. (2010) for 492 Scottish ombrotrophic mire. Our value for carbon sequestration of $9.13 \mathrm{t} \pm 0.98 \mathrm{t} \mathrm{CO} 2 \mathrm{e}$ $493 \mathrm{ha}^{-1} \mathrm{yr}^{-1}$ is at the upper limits of reported values, but is consistent with the figure of $49411.26 \mathrm{t} \pm 0.64 \mathrm{t} \mathrm{CO}_{2} \mathrm{e} \mathrm{ha}^{-1} \mathrm{yr}^{-1}$, derived from the analysis of dated cores at the same valley 495 mire site. This current study and that of Dinsmore et al. (2010) found that annual rates of 
carbon sequestration accounted for $60-70 \%$ of NPP. As in Dinsmore et al. (2010) the most

497 significant loss of $\mathrm{C}$ from the peat body in our study occurred via the aquatic $\mathrm{C}$ pathway

498

499

500

501

502

503

504

505

506

507

508

509

510

511

512

513

514

515

516

517

518

519

(Fig.6). Export of aquatic carbon accounted for $17 \%$ of the NEE. Under base flow conditions in our study, DOC and POC loads contributed equal proportions of the total organic carbon load (48\% and 51\%, respectively). Dinsmore et al. (2010) and Pawson et al. (2008) found higher losses of carbon under storm flow conditions and concluded that the release of POC was episodic. Evans and Warburton (2007) found that the POC component contributed on average $60 \%$ of the total organic carbon load on degraded peatland. Higher peat temperatures and water table draw-down produce higher soil DOC concentrations, indicating either increased biological production or increased aerobic oxidation (Fenner et al. 2005; Evans \& Warburton, 2007; Limpens et al. 2008).

In our study, variation in microform was observed with export of $\mathrm{CO}_{2}$ as $\mathrm{CH}_{4}$, accounting for over $24 \%$ of NECB for the pool microform, $11 \%$ for the lawn microform and $2 \%$ for the hummock microform (Fig. 6). This variation in $\mathrm{CH}_{4}$ export for microforms is consistent with that reported by other authors (Laine et al. 2009; Levy \& Gray, 2015; Kendal et al. 2018) who found that depth of water table was the key determinant of $\mathrm{CH}_{4}$ export.

\subsection{Optimal conditions for Sphagnum growth}

Sphagnum productivity is controlled by mean annual temperature, precipitation and photosynthetically active radiation (PAR) (Gunnarsson, 2005; Loisel et al. 2012; Nijp et al. 2015; Zhao et al. 2016). Dartmoor has limited seasonal variability and high precipitation, providing waterlogged conditions to retard decomposition processes and giving rise to an extended growing period. Lund et al. (2009) for northern peatland and tundra found that the length of the growing season was the most important variable describing the spatial variation in summertime gross primary production. 
520 Table 4 Changes in total seasonal precipitation from Dartmoor National Park (DNP) and 521 Plymouth between 1961 and 2015. Values show \% change from the mean, calculated by 522 subtracting the 1961-2015 mean from the 1961 - 2015 trend (linear least squares fit). Values 523 in brackets show the change in actual rainfall $(\mathrm{mm})$. Statistically significant linear trends, 524 using the seasonal Mann Kendall test, are denoted $* * P \leq 0.01,{ }^{*} P \leq 0.05$. Data source Met 525 Office (2016).

\begin{tabular}{|c|c|c|c|c|c|c|}
\hline & & & $\%$ change & total preci & ation $(\mathrm{m}$ & \\
\hline Location & Elevation & Spring & Summer & Autumn & Winter & Annual \\
\hline $\begin{array}{l}\text { Plymouth } \\
\text { Mountbatten }\end{array}$ & $50 \mathrm{~m}$ & $-5.4(11)$ & $\begin{array}{c}13.6 \\
(26.3)\end{array}$ & $7.7(22.1)$ & $\begin{array}{c}5.6 \\
(17.9)\end{array}$ & $5.2(52.4)$ \\
\hline $\begin{array}{l}\text { Double } \\
\text { Waters (DNP) }\end{array}$ & $355 \mathrm{~m}$ & $6(21)$ & $\begin{array}{l}* 23.2 \\
(82.7)\end{array}$ & $\begin{array}{l}* * 20.3 \\
(106.3)\end{array}$ & $\begin{array}{l}* * 20.9 \\
(20.9)\end{array}$ & $\begin{array}{l}* * 18.3 \\
(208.4)\end{array}$ \\
\hline $\begin{array}{l}\text { Hurston } \\
\text { Ridge (DNP) }\end{array}$ & $418 \mathrm{~m}$ & $-1.5(5.8)$ & $\begin{array}{c}12.6 \\
(40.1)\end{array}$ & $10(56.4)$ & $\begin{array}{c}13.9 \\
(97.6)\end{array}$ & $\begin{array}{l}* * 10.6 \\
(208.4)\end{array}$ \\
\hline $\begin{array}{l}\text { Princetown } \\
\text { (DNP) }\end{array}$ & $433 \mathrm{~m}$ & $6.6(26.1)$ & $\begin{array}{c}18.8 \\
(74.5)\end{array}$ & $\begin{array}{l}* 14.5 \\
(81.1)\end{array}$ & $\begin{array}{l}* 17.3 \\
(106)\end{array}$ & $\begin{array}{l}* * 14.8 \\
(289.7)\end{array}$ \\
\hline $\begin{array}{l}\text { White Ridge } \\
\text { (DNP) }\end{array}$ & $488 \mathrm{~m}$ & $\begin{array}{c}-3.6 \\
(15.3)\end{array}$ & $13.3(47)$ & $8.2(49.3)$ & $\begin{array}{c}11.3 \\
(85.4)\end{array}$ & $7.8(166.7)$ \\
\hline
\end{tabular}

526 Table 4 shows a significant increase in annual rainfall in three of the four Dartmoor sites. A

527 significant seasonal increase occurred in summer, autumn and winter at the Double Waters 528 site and autumn and winter at Princetown. Current climatic models for the UK (Murphy et al. 529 2018), predict ensemble-mean reductions of $26 \%$ for summer rainfall and therefore a 530 projected potential reduction in the size of the bioclimatic envelope for UK blanket bog

531 (Gallego-Sala \& Prentice, 2013). If such projections prove correct this may make peatlands in 532 the southwest of the UK marginal for future peat growth (Gallego-Sala et al. 2010). Table 4 533 shows a trend of increasing rainfall for all seasons apart from spring (March-May).

534 Particularly noteworthy are the increases in summer rainfall (June-August); which is 
significant at Double Waters, the most westerly windward upland site. Across all sites, average annual rainfall for 1961-2010 was $1968 \mathrm{~mm}$, compared with the mean for the study period (2011-2015) of $2165 \mathrm{~mm}$, an increase of $10 \%$.

South west UK has an optimal climate for Sphagnum growth with a long growing season associated with a warm, wet climate and limited seasonal variability compared with boreal and continental climates (Charman et al. 2013). In recent decades, Dartmoor has seen an increase in the length of the growing season for Sphagnum (number of days with minimum air temperatures above freezing), an increase in total rainfall and an increase in the number of contiguous days with rainfall. Krebs et al. (2016) modelled global biomass productivity of $S$. papillosum and found a step change increase in carbon sequestration when the mean duration of contiguous days with rain is longer than three days during the growth period.

\subsection{Response of modelled peatland bioclimatic envelope to climate change}

Many authors working with global climate models propose that there may be a decline in the strength of high latitude and tropical peatland carbon sinks throughout the $21^{\text {st }}$ century (Friedlingstein et al. 2006; Canadell et al. 2007; Limpens et al. 2008; Clark et al. 2010; House et al. 2010). Gallego-Sala and Prentice (2013) suggested that blanket bogs in southwest UK are at the lower limit of bioclimatic space and that, when future climate change scenarios were applied, a decline in the area of blanket peat was, according to their model, projected under both UKCIP02 high and low emission scenarios (Hulme et al. 2002). These modelled predictions do not appear to fit with the findings presented in this study for blanket bog in South West England. Our results for contemporary rates of carbon sequestration suggest that recent climate change may be having a positive effect on Sphagnum NPP and rates of carbon sequestration in rain-fed peatlands, due to increased precipitation and an extension in the length of the growing period for Sphagnum (Campbell et al. 2014; Krebs et 
559 al. 2016). Contrary to the bioclimatic envelope model predictions of Clark et al. (2010) and

560 House et al. (2010), our findings suggest that blanket bogs in south-west UK may have the

561 potential to act as a significant sink for $\mathrm{CO}_{2}$ under present upland climatic trends.

562 There is agreement amongst climate scientists that peatlands have had an important role in

563 past global cooling and that they have potential for significant negative feedbacks to the

564 climate system (Freeman et al., 1993; Gorham, 1995; Fenner, 2005; Roulet et al. 2007;

565 Limpens et al. 2008; Yu et al. 2012; Charman et al. 2013). Peatland ecosystems are the most 566 efficient carbon store of all terrestrial ecosystems (Brooks \& Stoneman, 1997; Worrall et al.

567 2003) and retaining active peatlands is one of the most cost-effective measures in achieving

568 zero net global carbon emissions (Ostle et al. 2009; Lindsay, 2010). Actively growing

569 peatlands are important in the global $\mathrm{C}$ cycle, capturing atmospheric $\mathrm{CO}_{2}$ emissions and have

570 the potential to make a significant contribution over 100-year timescales.

\section{$571 \quad 5.0$ Conclusions and future research challenges}

572 This paper reports mean rates of $\mathrm{CO}_{2}$ sequestration for Sphagna of

$5739.13 \mathrm{t} \pm 0.98 \mathrm{t} \mathrm{CO}_{2} \mathrm{e} \mathrm{ha}^{-1} \mathrm{yr}^{-1}$ and carbon accumulation rates from peat cores dated to 1850 of

$57411.26 \mathrm{t} \pm 0.68 \mathrm{t} \mathrm{CO}_{2} \mathrm{e} \mathrm{ha}^{-1} \mathrm{yr}^{-1}$ for valley mire and $11.77 \mathrm{t} \pm 0.88 \mathrm{t} \mathrm{CO}_{2} \mathrm{e} \mathrm{ha}^{-1} \mathrm{yr}^{-1}$ for blanket

575 bog from an oceanic peatland setting in southwest England. These values are much higher

576 than the uncertainty range for rates of carbon accumulation in undrained/rewetted peatlands

577 reported in the IPCC Wetlands Supplement met-analysis (Blain et al. 2014). The IPCC values

578 do not incorporate local variability and are much lower than values for temperate peatlands

579 reported recently (Laine et al. 2009; Campbell et al. 2014; Wilson et al. 2016). Our findings,

580 together with other studies (Levy \& Gray 2015; Ratcliffe et al. 2018), where NEE and NECB

581 models have been used to measure the strengths of carbon sinks, suggest that using past rates 
582

583

584

585

586

587

588

589

590

591

592

593

594

595

596

597

598

599

600

601

602

603

604

of peat growth based on peat cores provides an underestimate of contemporary rates of $\mathrm{CO}_{2}$ sequestration.

Recent changes in climate appear to have had no impact on the strength of peatland carbon sinks in South West England. Past and contemporary peatland carbon sinks on our study sites located in South West England were found to be at the upper limits of those reported in the literature for temperate peatlands. This finding suggest that recent bioclimatic envelope models (Clarke et al. 2010; House et al. 2010; Gallego-Saga et al. 2013) may underestimate the potential future contribution that UK peatlands can make to carbon sequestration under observed climatic trends. Temperate oceanic peatlands offer one of the more viable and achievable options for long term storage of carbon fixed by photosynthesis under present climate trends.

This study highlights how peatland carbon sinks have responded to anthropogenic climate change and historic anthropogenic impacts, comparing contemporary rates of carbon sequestration with past rates of carbon accumulation for the same site. Findings suggest that, contrary to expectations based on bioclimatic envelope models, peatland carbon sequestration rates in South West England are stable and possibly increasing, due to amongst other factors, altered patterns of precipitation amount and frequency .

\subsection{Acknowledgements}

We thank all of the postgraduate students from the MSc Environmental Consultancy programme who have been instrumental in methodological refinement and data collection.

Particular thanks go to Heather Runnacles-Goodridge, Tomos Hughes, Simon Caine, Rebecca Coombes, Fiona Waldron, Lottie Miles and Alice Hughes. Undergraduate students from the BSc Environmental Science programme include Daniella Pascoe and Laurie Spacie.

605 Particular thanks also to Frances Cooper of the Dartmoor Mires Project and Norman Baldock 
606 from DNPA; to Andrew Tonkin for help with laboratory work; Richard Hartley and Dr

607 Andrew Williams for help with field work.

608

609

610

611

612

613

614

615

616

617

618

619

620

621

622

623

624

625

626

627

628

629

\subsection{References}

Aaby B, Tauber H (1975) Rates of peat formation in relation to humification and local environment as shown by study of a raised bog in Denmark. Boreas, 4, 1-17.

Bain CG, Bonn A, Stoneman R, Chapman S, et al. (2011) IUCN UK Commission of Inquiry on Peatlands, 1-112. IUCN UK Peatland Programme, Edinburgh.

Barber KE, Chambers FM, Maddy D, et al. (1994) A sensitive high-resolution record of lateHolocene climatic change from a raised bog in northern England. The Holocene, 4, 200-207. Belyea L, Clymo RS (2001) Feedback control in the rate of peat formation. Proceedings of the Royal Society of London. Series B: Biological Sciences, 268, 1315-1321.

Belyea LR, Malmer N (2004) Carbon sequestration in peatland: patterns and mechanisms of response to climate change. Global Change Biology, 10, 1043-1052.

Billett MF, Charman DJ, Clark JM, Evans CD et al. (2010) Carbon balance of UK peatlands: current state of knowledge and future research challenges. Climate Research, 45, 13-29.

Blain D, Murdiyarso D, Couwenberg J et al. (2014) Chapter 3. Rewetted organic soils. In:

Hiraishi T, Krug T, Tanabe K, et al. (eds.), 2013 Supplement to the 2006 IPCC Guidelines for National Greenhouse Gas Inventories: Wetlands. Intergovernmental Panel on Climate Change, Switzerland.

Botch MS, Masing VV (1983) Mire ecosystems in the U.S.S.R. In: Mires; swamp, bog, fen and moor; regional studies (ed AJP Gore), Ecosystems of the world, 48, 95-152. Elsevier, Oxford, UK.

Brooks S, Stoneman R (1997) Conserving Bogs: The Management Handbook. The Stationary Office Limited, Edinburgh, UK. 
630 Buffam I, Carpenter SR, Yeck W, Hanson PC, Turner MG (2010) Filling holes in regional 631 carbon budgets: predicting peat depth in a north-temperate lake district. Journal of

632 Geophysical Research: Biogeosciences, 115, G01005, doi: 01010.01029/ 02009JG001034.

633 Campbell D, Smith J, Goodrich J, Wall A, Schipper L (2014) Year-round growing conditions 634 explains large $\mathrm{CO}_{2}$ sink strength in a New Zealand raised peat bog. Agricultural and Forest 635 Meteorology, 192-193. 59-68. 10.1016/j.agrformet.2014.03.003.

636 Canadell JG, Pataki D, Gifford R, Houghton RA, Lou Y, Raupach MR, Smith P, Steffen W 637 (2007) Terrestrial Ecosystems in a Changing World. International Geosphere-Biosphere 638 Programme Series (eds Canadell J G, Pataki D, Pitelka L) pp. 59-78, Springer, Berlin, 639 Germany.

640 Chambers F, Charman D (2004) Holocene environmental change: contributions from the 641 peatland archive. The Holocene, 14 (1), 1-6.

642 Chambers FM, Beilman DW, Yu Z (2011) Methods for determining peat humification and 643 for quantifying peat bulk density, organic matter and carbon content for palaeostudies of 644 climate and peatland carbon dynamics. Mires and Peat, 7, 1-10.

645 Chapin FS, Woodwell GM, Randerson JT, et al. (2006) Reconciling carbon-cycle concepts, 646 terminology, and methods. Ecosystems, 9, 1041-1050.

647 Charman D (2002) Peatlands and Environmental Change, pp. 1-301. John Wiley \& Sons 648 Ltd, Chichester, UK

649 Charman DJ, Beilman DW, Blaauw M et al. (2013) Climate-related changes in peatland 650 carbon accumulation during the last millennium. Biogeosciences, 10 (2), 929-944.

651 Christian MM, Pejcic B, Esteban L, Delle Piane C, Raven M, Mizaikoff B (2014) Infrared 652 Attenuated Total Reflectance Spectroscopy: An Innovative Strategy for Analyzing Mineral 653 Components in Energy Relevant Systems. Scientific Reports, 4, Article number 6764. 
654 Clark JM, Gallego-Sala AV, Allott TEH et al. (2010) Assessing the vulnerability of blanket 655 peat to climate change using an ensemble of statistical bioclimatic envelope models. Climate 656 Research, 45, 131-150.

657 Clymo RS (1970) The Growth of Sphagnum: Methods of Measurement. Journal of Ecology, $658 \mathbf{5 8}(1), 13-49$.

659 Clymo RS (1984) The limits to peat bog growth. Proceedings of the Royal Society of London 660 $B, \mathbf{3 0 3}, 605-654$.

661 Clymo RS, Pearce DME (1995) Methane and carbon dioxide production in, transport 662 through, and efflux from a peatland. Philosophical Translations of the Royal Society of 663 London A, 351, 249-259.

664 Clymo RS, Turunen J, Tolonen K (1998) Carbon accumulation in peatland, Oikos, 81, 368665388.

666 Cox P, Betts R, Jones C, Spall S, Totterdell I (2000) Acceleration of global warming due to 667 carbon-cycle feedbacks in a coupled climate model. Nature, 408, 184-187.

668 Dinsmore KJ, Billett MF, Skiba UM, Rees RM, Helfter C (2010) Role of the aquatic pathway 669 in the carbon and greenhouse gas budgets of a peatland catchment. Global Change Biology, $670 \quad 16,2750-2762$.

671 Dixon, S.D., Qassim, S.M., Rowson, J.G., Worrall, F., Evans, M.G., Boothroyd, I.M. \& 672 Bonn, A. (2014) Restoration effects on water table depths and $\mathrm{CO}_{2}$ fluxes from climatically 673 marginal blanket bog. Biogeochemistry, 118(1-3), 159-176.EMASyst (1996) Elemental

674 Analyser Data System, Operation and Installation Manual, Version 4.5.01

675 Evans M, \& Warburton J (2007) The geomorphology of upland peat: pattern, process, form, 676 pp. 262. Blackwell, Oxford. 
677 Fenner N, Freeman C, Reynolds B (2005) Hydrological effects on the diversity of phenolic 678 degrading bacteria in a peatland, implications for carbon cycling. Soil Biology and 679 Biochemistry, 37, 1277-87.

680 Freeman C, Lock MA, Reynolds B (1993) Fluxes of $\mathrm{CO}_{2}, \mathrm{CH}_{4}$ and $\mathrm{N}_{2} \mathrm{O}$ from a Welsh 681 peatland following simulation of water table draw down - potential feedback to climatic682 change. Biogeochemistry, 19, 51-60.

683 Friedlingstein P, Cox PM, Betts RA et al. (2006) Climate-carbon cycle feedback analysis:

684 Results from the $\mathrm{C}^{4} \mathrm{MIP}$ model intercomparison. Journal of Climate, 19, 3337-3353.

685 Friedlingstein PRM, Andrew J, Rogelj GP et al. (2014) Persistent growth of $\mathrm{CO}_{2}$ emissions 686 and implications for reaching climate targets. Nature Geoscience, 7, 709-715.

687 Joosten H, Tanneberger F, Moen A (eds.) (2017) In Mires and peatlands of Europe: Status, 688 distribution and conservation (2017) Stuttgart: Schweitzerbart Science Publishers), 780pp. SJ (2010) Bioclimatic envelope model of climate change impacts on blanket peat distribution

691 in Great Britain. Climate Research, 45, 151-162.

692 Gallego-Sala AV, Prentice IC (2013). Blanket peat biome endangered by climate change. 693 Nature Climate Change, 3(2), 152-155. DOI: 10.1038/NCLIMATE1672.

694 Gatis N, Luscombe D, Carless D, Parry LE, Fyfe RM, Harrod T, Brazier RE, Anderson K 695 (2019) Mapping upland peat depth using airborne radiometric and LiDAR survey data 696 Geoderma, 335, 78-87.

697 Gatis N, Luscombe DJ, Grand-Clement E, Hartley IP, Anderson K, Smith D, Brazier RE 698 (2015) The effect of drainage ditches on vegetation diversity and $\mathrm{CO}_{2}$ fluxes in a Molinia 699 caerulea-dominated peatland. Ecohydrology, 9 (3), DOI: 10.1002/eco.1643.

700 Gorham E (1991) Northern peatlands: role in the carbon cycle and probable responses to 701 climate warming. Ecological Applications, 1, 182-195. 
702 Gorham E (1995) The biogeochemistry of northern peatlands and its possible response to 703 global warming. In: Biotic Feedbacks in the Global Climatic System (eds Woodwell GM,

704 Mackenzie FT), pp. 169-187. Oxford University Press, New York.

705 Green SM, Baird AJ, Evans CD, Peacock M, Holden J, Chapman PJ, Smart RP (2018)

706 Methane and carbon dioxide fluxes from open and blocked ditches in a blanket bog. Plant and 707 Soil, 424 (1-2), 619-638. 10.1007/s11104-017-3543-z.

708 Gunnarsson U (2005) Global patterns of Sphagnum productivity. Journal of Bryology, 27, $709 \quad 269-279$.

710 Helfter C, Campbell C, Dinsmore KJ, Drewer J, Coyle M, Anderson M, Skiba U, Nemitz E, 711 Billett MF, Sutton MA (2015) Drivers of long-term variability in $\mathrm{CO}_{2}$ net ecosystem 712 exchange in a temperate peatland, Biogeosciences, 12, 1799-1811, 713 https://doi.org/10.5194/bg-12-1799-2015

714 Holden J, Shotbolt L, Bonn A, Burt TP et al. (2007) Environmental change in moorland 715 landscapes. Earth-Science Reviews, 2, 75-100.

716 Hope D, Billett, MF, Cresser MS (1994) A review of the export of carbon in river water:

717 Fluxes and processes. Environmental Pollution, 84: 301-324.

718 House JI, Orr HG, Clark JM, Gallego-Sala AV, Freeman C, Prentice IC, Smith P (2010)

719 Climate change and the British Uplands: evidence for decision-making. Climate Research, $720 \quad 45,3-12$.

721 Hulme M, Jenkins GL, Lu X, Turnpenny JR et al. (2002) Climate change scenarios for the 722 United Kingdom: the UKCIP02 scientific report, pp. 1-124. Tyndall Centre for Climate 723 Change Research, School of Environmental Sciences, University of East Anglia, Norwich, 724 UK.

725 Janssens IA, Freibauer A, Schlamadinger B et al. (2005) The carbon budget of terrestrial 726 ecosystems at country-scale - a European case study. Biogeosciences, 2, 15-26. 
727 Kandel, T.P., Lærke, P.E. \& Elsgaard, L. (2018) Annual emissions of $\mathrm{CO}_{2}, \mathrm{CH}_{4}$ and $\mathrm{N}_{2} \mathrm{O}$

728 from a temperate peat bog: Comparison of an undrained and four drained sites under

729 permanent grass and arable crop rotations with cereals and potato. Agricultural and Forest

730 Meteorology, 256-257, 470-481.

731 Koehler AK, Sottocornola M, Kiely G (2011) How strong is the current carbon sequestration

732 of an Atlantic blanket bog? Global Change Biology, 17, 309-319. doi:10.1111/j.1365-

$733 \quad 2486.2010 .02180 . x$

734 Krebs M, Gaudig G, Joosten H (2016) Record growth of Sphagnum papillosum in Georgia

735 (Transcaucasus): rain frequency, temperature and microform as key drivers in natural bogs.

736 Mires and Peat, 18 (4), 1-16.

737 Laine A, Byrne KA, Kiely G, Tuittila ES (2009) The short-term effect of altered water level 738 on carbon dioxide and methane fluxes in a blanket bog. Suo, 60, 65-83.

739 Levy PE, Gray A (2015) Greenhouse gas balance of a semi-natural peatbog in northern

740 Scotland. Environmental Research Letters, 10 (9). https://doi.org/10.1088/1748-

$741 \underline{9326 / 10 / 9 / 094019}$

742 Limpens J, Berendse F, Blodau C et al. (2008) Peatlands and the carbon cycle: from local

743 processes to global implications - a synthesis. Biogeosciences, 5, 1475-1491.

744 Lindsay R (2010) Peatbogs and carbon: a critical synthesis to inform policy development in

745 oceanic peat bog conservation and restoration in the context of climate change. Report to

$746 \quad R S P B$ Scotland, pp.1-344. Edinburgh.

747 Lindsay R, Clough J (2017) In Mires and peatlands of Europe: Status, distribution and 748 conservation (2017) H Joosten, F Tanneberger and A Moen A (eds.) Stuttgart: Schweitzerbart

749 Science Publishers), 780pp. 
750 Loisel J, Gallego-Sala AV, Yu Z (2012) Global-scale pattern of peatland Sphagnum growth

751

752

753

754

755

756

757

758

759

760

761

762

763

764

765

766

767

768

769

770

771

772

773

774 driven by photosynthetically active radiation and growing season length. Biogeosciences, $\mathbf{9}$, $2737-2746$.

Lund M, Lafleur PM, Roulet NT et al. (2009) Variability in exchange of $\mathrm{CO}_{2}$ across twelve northern peatland and tundra sites. Global Change Biology, 16, 2436-2448.

Lütt S (1992) Produktionsbiologische Untersuchungen zur Sukzession der Torfstichvegetation in Schleswig-Holstein (Research on Productivity of the Succession of Peat Pit Vegetation in Schleswig-Holstein), pp. 250. Mitteilungen der Arbeitsgemeinschaft Geobotanik in Schleswig-Holstein und Hamburg, 43, Kiel.

McNeil P, Waddington J M (2003) Moisture controls on Sphagnum growth and $\mathrm{CO}_{2}$ exchange on a cutover bog. Journal of Applied Ecology, 40, 354-367.

Met Office (2017) Historic regional climate data. [Online]

<http://www.metoffice.gov.uk/datapoint/product/regional-climate> [accessed 20/11/2018] Minke M, Augustin J, Burlo A, Yarmashuk T, Chuvashova H, Thiele A, Freibauer A, Tikhonov V, Hoffmann M (2016) Water level, vegetation composition, and plant productivity explain greenhouse gas fluxes in temperate cutover fens after inundation. Biogeosciences, 13 (13), 3945-3970.

Moore TR, Bubier JL, Frolking SE, Lafleur PM, Roulet NT (2002) Plant biomass and production and $\mathrm{CO}_{2}$ exchange in an ombrotrophic bog. Journal of Ecology, 90, 25-36. Moore TR, Roulet NT (1991) A comparison of dynamic and static chambers for the measurement of methane flux from subarctic fens. Atmosphere-ocean, 29, 102-109. Murphy JM, Harris GR, Sexton DMH et al. (2018) UKCP18 Land Projections: Science Report. Met Office Hadley Centre, Exeter. https://www.metoffice.gov.uk/pub/data/weather/uk/ukcp18/science-reports/UKCP18-Landreport.pdf (last accessed 03/12/18) 
775 Myhre G, Shindell D, Bréon FM et al. (2013) Anthropogenic and Natural Radiative Forcing. 776 In: Stocker T. F., Qin D., Plattner G.-K., et al. (eds.), Climate Change 2013: The Physical 777 Science Basis. Contribution of Working Group I to the Fifth Assessment Report of the 778 Intergovernmental Panel on Climate Change. Cambridge University Press, Cambridge, 779 United Kingdom and New York, NY, USA, 659-740 pp.

780 Nijp JJ, Limpens J, Metselaar K, Peichl M, Nilsson MB, van der Zee SE, Berendse F (2015) 781 Rain events decrease boreal peatland net $\mathrm{CO}_{2}$ uptake through reduced light availability. 782 Global Change Biology, 21, 2309-2320.

783 Nilsson M, Sagerfors J, Buffam I et al. (2008) Contemporary carbon accumulation in a boreal 784 oligotrophic minerogenic mire - a significant sink after accounting for all C-fluxes. Global 785 Change Biology, 14, 1-16.

786 Ostle NJ, Levy PE, Evans CD, Smith P (2009) UK land, sea and soil carbon sequestration. 787 Land Use Policy, 265, 274-283.

788 Parish F, Sirin A, Charman D, Joosten H, Minayeva T, Silvius M, Stringer L (eds) (2008) 789 Assessment on Peatlands, Biodiversity and Climate Change: Main Report. Global 790 Environment Centre, Kuala Lumpur and Wetlands International, Wageningen. Available at: 791 $\leq \underline{\text { http://www.imcg.net/media/download_gallery/books/assessment_peatland.pdf. }}$.

792

793 $[16 / 11 / 2018]$

Pawson RR, Lord DR, Evans MG, Allott TEH (2008) Fluvial organic carbon flux from an eroding peatland catchment, southern Pennines, UK. Hydrology and Earth System Sciences, $12,625-634$.

Payne RJ, Malysheva E, Tsyganov A, Pampura T, Novenko E, Volkova E, Babeshko K, Mazei Y (2016) A multi-proxy record of Holocene environmental change, peatland development and carbon accumulation from Staroselsky Moch peatland, Russia. The Holocene, 26, 314-326. 
800 Pendea IF, Chmura GI (2012) A high-resolution record of carbon accumulation rates during 801 boreal peatland initiation. Biogeosciences, 9, 2711-2717.

802 Ratcliffe J, Andersen R, Anderson R et al. (2018). Contemporary carbon fluxes do not reflect 803 the long-term carbon balance for an Atlantic blanket bog. The Holocene, 28 (1), 140-149.

804 DOI: $10.1177 / 0959683617715689$

805 Riutta T, Laine J, Tuittila ES (2007) Sensitivity of $\mathrm{CO}_{2}$ exchange of fen ecosystem 806 components to water level variation. Ecosystems, 10, 718-733.

807 Rodwell JS (ed) 1991 British Plant Communities Volume 2. Mires and Heaths Cambridge 808 University Press.

809 Rose NL, Appleby PG (2005) Regional applications of lake sediment dating by spheroidal 810 carbonaceous particle analysis. I: United Kingdom. Journal of Paleolimnology, 34, 349-361. 811 Rose NL, Harlock S, Appleby PG, Battarbee RW (1995) Dating of recent lake sediments in

812 the United Kingdom and Ireland using spheroidal carbonaceous particle (SCP) concentration 813 profiles. The Holocene, 5, 328-335.

814 Roulet NT, Lafleur PM, Richard PJH, Moore TR, Humphreys ER, Bubier J (2007)

815 Contemporary carbon balance and late Holocene carbon accumulation in a northern peatland.

816 Global Change Biology, 13, 397-411.

817 Rowson JG, Gibson HS, Worrall F, Ostle N, Burt TP, Adamson JK (2010) The complete

818 carbon budget of a drained peat catchment. Soil Use and Management, 26, 261-273.

819 Siegel S, Castellan NJ Jr (1988) Nonparametric statistics for the behavioural sciences, 2nd 820 edn., pp. 399. McGraw-Hill, New York, USA.

821 Swindles G (2010) Dating recent peat profiles using spheroidal carbonaceous particles 822 (SCPs). Mires and Peat, 7 (3), 1-5.

823 Tallis JH (1998) Growth and degradation of British and Irish blanket mires. Environmental 824 Reviews, 6, 81-122. 
825 Turunen J, Tomppo E, Tolonen K et al. (2002) Estimating carbon accumulation rates of 826 undrained mires in Finland - application to boreal and subarctic regions. The Holocene, 12, $827 \quad 69-80$.

828 Ukonmaanaho L, Nieminen TM, Rausch N, Cheburkin A, Le Roux G, Shotyk W (2006)

829 Recent organic matter accumulation in relation to some climatic factors in ombrotrophic peat 830 bogs near heavy metal emission sources in Finland. Global and Planetary Change, 53 (4), $831259-268$.

832 Utstøl-Klein S, Halvorsen R, Ohlson M (2015) Increase in carbon accumulation in a boreal 833 peatland following a period of wetter climate and long-term decrease in nitrogen deposition. 834 New Phytologist, 206, 1238-1246.

835 Vitt DH, Halsey LA, Bauer IE, Campbell C (2000) Spatial and temporal trends in carbon 836 storage of peatlands of continental western Canada through the Holocene. Canadian Journal 837 of Earth Sciences, 37, 683-693.

838 Waddington JM, Strack M, Greenwood MJ (2010) Toward restoring the net carbon sink 839 function of degraded peatlands: Short-term response in $\mathrm{CO}_{2}$ exchange to ecosystem-scale 840 restoration. Journal of Geophysical Research, 115, 1-13. doi:10.1029/2009JG001090.

841 Wilson D, Farrell C, Fallon D, Moser G, Muller C, Renou-Wilson F (2016) Multi-year 842 greenhouse gas balances at a rewetted temperate peatland. Global Change Biology, 22, 4080843 4095, DOI: 10.1111/gcb.13325.

844 Worrall F, Burt TP, Rowson JG, Warburton J, Adamson JK (2009) The multi-annual carbon 845 budget of a peat-covered catchment. Science of the Total Environment, 407, 4084-4094.

846 Worrall F, Reed M, Warburton J et al. (2003) Carbon budget for a British upland peat

847 catchment. The Science of the Total Environment, 312, 133-146.

848 Wright WHK (1884). The Western Antiquary, Volume 3. Publisher Latimer \& Son, 849 Plymouth. Sonhttps://archive.org/details/westernantiquar06wriggoog Last accessed 19/10/18 
850 Xu J, Morris PJ, Liu J, Holden J (2018) PEATMAP: Refining estimates of global peatland 851 distribution based on a meta-analysis. Catena, 160, 134-140.

852 Doi.org/10.1016/j.catena.2017.09.010

853 Yu Z (2011a) Holocene carbon flux histories of the world's peatlands: Global carbon-cycle 854 implications. The Holocene, 21 (5), 761-774.

855 Yu Z, Beilman DW, Frolking S, MacDonald GM, Roulet NT, Camill P, Charman DJ (2011b)

856 Peatlands and Their Role in the Global Carbon Cycle. Eos, Transactions American

857 Geophysical Union, 92 (12), 97.

858 Yu ZC 2012. Northern peatland carbon stocks and dynamics: A review. Biogeosciences, 9 , $859 \quad 4071-4085$.

860 Zhao J, Peichl M, Öquist M, Nilsson MB (2016) Gross primary production controls the

861 subsequent winter $\mathrm{CO}_{2}$ exchange in a boreal peatland. Global Change Biology, 22 (12). 862 doi:10.1111/gcb.13308. 